\title{
Measurement of Evapotranspiration in Phreatophyte Areas, Smith Creek Valley and Carson Desert, West-Central Nevada, 1983
}

\section{By R.L. CARMAN}

\section{A product of the Regional}

Aquifer-System Analysis of the

Great Basin-Nevada, Utah,

and adjacent States 


\section{U.S. DEPARTMENT OF THE INTERIOR BRUCE BABBITT, Secretary}

U.S. GEOLOGICAL SURVEY

Robert M. Hirsch, Acting Director

Any use of trade, product, or firm names

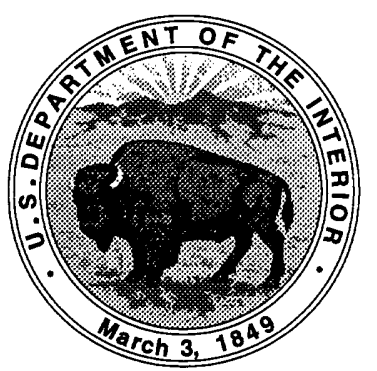

in this publication is for descriptive purposes only

and does not imply endorsement by the U.S. Government

UNITED STATES GOVERNMENT PRINTING OFFICE: 1993

For additional information

write to:

District Chief

U.S. Geological Survey

333 West Nye Lane, Room 203

Carson City, NV 89706-0866
Copies of this report can be purchased from:

U.S. Geological Survey Earth Science Information Center Open-File Reports Section Box 25286, MS 517 Denver Federal Center Denver, CO 80225-0046 


\title{
CONTENTS
}

\author{
Abstract 1 \\ Introduction $\mathbf{1}$ \\ Background 1 \\ Purpose and scope 1 \\ Acknowledgments 2 \\ Description of study sites $\mathbf{2}$ \\ Evapotranspiration $\mathbf{2}$ \\ Energy-transport mechanisms $\mathbf{3}$ \\ Methods of measurement 4 \\ Instrumentation $\mathbf{5}$ \\ Equations for calculating evapotranspiration 7 \\ Data summary 9 \\ Correlations 12 \\ Transfer value 18 \\ Summary and conclusions 18 \\ References cited 18
}

\section{FIGURES}

1. Map showing location of study sites 3

2. Graph showing monthly average precipitation and temperature for Smith Creek Valley and Soda Lake, 19834

3. Sketch of processes involved in transport of heat and vapor into atmosphere $\mathbf{5}$

4. Photograph showing instrumentation for eddy-correlation method 6

5. Photograph showing instrumentation for Bowen ratio method 7

6. Photograph showing instrumentation for Penman method 8

7-14. Graphs showing:

7. Heat flux determined by eddy-correlation method at Smith Creek Valley and Soda Lake sites 12

8. Potential-evapotranspiration values and Penman weather-station data showing effects of inclement weather at Smith Creek Valley and Soda Lake sites, May 31 through June 5, $1983 \mathbf{1 3}$

9. Total daily evapotranspiration at Smith Creek Valley and Soda Lake sites, April through September 198314

10. Total evapotranspiration estimated by eddy-correlation method for areas dominated by rabbitbrush and greasewood at Smith Creek Valley site, September 16-20, 198314

11. Evapotranspiration values derived from measured and residual latent-heat fluxes at Smith Creek Valley and Soda Lake sites, April through September 198315

12. Measured and residual latent-heat flux values at Smith Creek Valley site, September 18, $1983 \quad 16$

13. Relation between potential evapotranspiration and solar radiation at Smith Creek Valley site 16

14. Relation between actual and potential evapotranspiration at Smith Creek Valley and Soda Lake sites, April through September 198317

\section{TABLES}

1. Evapotranspiration determined by different methods for selected days during 1983 in Smith Creek Valley and vicinity $\mathbf{1 0}$

2. Evapotranspiration determined by different methods for selected days during 1983 near Soda Lake 11

3. Total evapotranspiration for 1983 derived from measured and residual values of latent-heat flux $\mathbf{1 5}$ 


\begin{tabular}{|c|c|c|}
\hline Multiply & By & To obtain \\
\hline \multicolumn{3}{|c|}{ Energy and power } \\
\hline joule per gram $(\mathrm{J} / \mathrm{g})$ & 0.4299 & British thermal unit per pound \\
\hline joule per gram per degree Celsius $\left(\mathrm{J} / \mathrm{g} /{ }^{\circ} \mathrm{C}\right)$ & 0.2390 & $\begin{array}{l}\text { British thermal unit per pound per } \\
\text { degree Fahrenheit }\end{array}$ \\
\hline megajoule per square meter $\left(\mathrm{MJ} / \mathrm{m}^{2}\right)$ & 88.08 & British thermal unit per square foot \\
\hline watt per square meter $\left(\mathrm{W} / \mathrm{m}^{2}\right)$ & 0.3172 & $\begin{array}{l}\text { British thermal unit per square foot } \\
\text { per hour }\end{array}$ \\
\hline \multicolumn{3}{|c|}{ Mass } \\
\hline cubic meter per gram $\left(\mathrm{m}^{3} / \mathrm{g}\right)$ & & cubic foot per pound \\
\hline cubic meter squared per gram squared $\left(\mathrm{m}^{6} / \mathrm{g}^{2}\right)$ & & cubic foot squared per pound squared \\
\hline gram per square centimeter per second $\left(\mathrm{g} / \mathrm{cm}^{2} / \mathrm{s}\right)$ & 0.01422 & pound per square inch per second \\
\hline gram per square meter per second $\left(\mathrm{g} / \mathrm{m}^{2} / \mathrm{s}\right)$ & 0.0002048 & pound per square foot per second \\
\hline gram per cubic meter $\left(\mathrm{g} / \mathrm{m}^{3}\right)$ & 0.00006243 & pound per cubic foot \\
\hline gram per cubic meter per kelvin $\left(\mathrm{g} / \mathrm{m}^{3} / \mathrm{K}\right)$ & 0.00006243 & pound per cubic foot per kelvin \\
\hline \multicolumn{3}{|c|}{ Length } \\
\hline centimeter $(\mathrm{cm})$ & 0.3937 & inch \\
\hline meter $(\mathrm{m})$ & 3.281 & foot \\
\hline kilometer $(\mathrm{km})$ & 0.6214 & mile \\
\hline \multicolumn{3}{|c|}{ Velocity or rate } \\
\hline millimeter per second $(\mathrm{mm} / \mathrm{s})$ & 0.003281 & foot per second \\
\hline meter per second $(\mathrm{m} / \mathrm{s})$ & 2.237 & mile per hour \\
\hline meter per second per count $(\mathrm{m} / \mathrm{s} / \mathrm{ct})$ & 3.281 & foot per second per count \\
\hline centimeter per day $(\mathrm{cm} / \mathrm{d})$ & 0.3937 & inch per day \\
\hline second per meter $(\mathrm{s} / \mathrm{m})$ & 0.3048 & second per feet \\
\hline centimeter per year $(\mathrm{cm} / \mathrm{yr})$ & 0.3937 & inch per year \\
\hline meter per year $(\mathrm{m} / \mathrm{yr})$ & 3.281 & foot per year \\
\hline kilometer per hour $(\mathrm{km} / \mathrm{hr})$ & 0.6214 & mile per hour \\
\hline
\end{tabular}

For temperature, degrees Celsius $\left({ }^{\circ} \mathrm{C}\right)$ may be converted to degrees Fahrenheit $\left({ }^{\circ} \mathrm{F}\right)$ by using the formula ${ }^{\circ} \mathrm{F}=\left[1.8\left({ }^{\circ} \mathrm{C}\right)\right]+32$. Kelvins $(\mathrm{K})$ may be converted to degrees Fahrenheit $\left({ }^{\circ} \mathrm{F}\right)$ by using the formula ${ }^{\circ} \mathrm{F}=[1.8(\mathrm{~K})]-459.67$.

Sea Level: In this report, "sea level" refers to the National Geodetic Vertical Datum of 1929 (NGVD of 1929, formerly called Sea Level Datum of 1929), which is derived from a general adjustment of the first-order leveling networks of the United States and Canada. 


\section{SYMBOLS AND UNITS}

Definition

Unit

$a \quad$ Calibration constant for Lyman alpha hygrometer.

$\mathrm{m}^{3} / \mathrm{g}$

A Altitude above sea level.

$\mathrm{m}$

$b \quad$ Calibration constant for Lyman alpha hygrometer.

$\mathrm{m}^{6} / \mathrm{g}^{2}$

$C_{\mathrm{f}} \quad$ Calibration constant for fine-wire thermocouple.

${ }^{\circ} \mathrm{C}$

$C_{\mathrm{p}} \quad$ Specific heat of air.

$C_{\rho_{\mathrm{v}} \mathrm{u}} \quad$ Covariance of vapor density and vertical wind velocity as measured counts by data logger.

$C_{\mathrm{s}} \quad$ Calibration constant for sonic anemometer.

$\mathrm{m} / \mathrm{s} /$ count

$C_{\mathrm{v}_{1} \mathrm{v}_{2}}$

Covariance of voltages from sonic anemometer and fine-wire thermocouple, as recorded by data logger.

d Zero-plane displacement.

$E \quad$ Water-vapor-flux density.

$G \quad$ Soil-heat flux.

$h \quad$ Average crop height.

$H \quad$ Sensible-heat flux.

$k \quad$ Von Karman's constant.

$L_{\mathrm{n}} \quad$ Net long-wave radiation.

counts

$\mathrm{m}$

$\mathrm{g} / \mathrm{m}^{2} / \mathrm{s}$

$\mathrm{W} / \mathrm{m}^{2}$

$\mathrm{m}$

$\mathrm{W} / \mathrm{m}^{2}$

$\mathrm{W} / \mathrm{m}^{2}$

Heat-transfer resistance.

$\mathrm{s} / \mathrm{m}$

Vapor-transfer resistance.

$\mathrm{s} / \mathrm{m}$

$r_{\mathrm{v}}$

Downward long-wave radiation.

$\mathrm{W} / \mathrm{m}^{2}$

Upward long-wave radiation.

$\mathrm{W} / \mathrm{m}^{2}$

$\begin{array}{ll}R_{\mathrm{l}} & \text { Upward long-wave } \\ R_{\mathrm{n}} & \text { Net solar radiation. }\end{array}$

$\mathrm{W} / \mathrm{m}^{2}$

$R_{\mathrm{S}} \quad$ Global short-wave radiation.

$\mathrm{MJ} / \mathrm{m}^{2}$

$S \quad$ Slope of saturation vapor-density curve.

$\mathrm{g} / \mathrm{m}^{3 /} /{ }^{\circ} \mathrm{C}$

Temperature.

${ }^{\circ} \mathrm{C}$

Absolute temperature.

$\mathrm{K}$

$\mathrm{K}$

Average wind velocity.

$\mathrm{m} / \mathrm{s}$

Heat- and vapor-roughness parameter. $\mathrm{m}$

$z_{\mathrm{h}} \quad$ Heat- and vapor-roughness parameter.
$z_{\mathrm{m}} \quad$ Momentum-roughness parameter.

$z_{\mathrm{m}} \quad$ Momentum-roughness parameter.

$Z \quad$ Instrument height above land surface. $\mathrm{m}$

$\alpha_{\mathrm{s}} \quad$ Surface albedo.

$\beta \quad$ Bowen ratio.

$\gamma \quad$ Thermodynamic psychrometric constant.

$\mathrm{g} / \mathrm{m}^{3} /{ }^{\circ} \mathrm{C}$

Apparent psychrometric constant.

$\mathrm{g} / \mathrm{m}^{3} /{ }^{\circ} \mathrm{C}$

$\varepsilon_{\mathrm{a}} \quad$ Clear-sky emissivity.

$\varepsilon_{\mathrm{s}} \quad$ Surface emissivity.

$\lambda \quad$ Latent heat of vaporization. $\quad \mathrm{J} / \mathrm{g}$

$\lambda E \quad$ Latent-heat flux.

$\mathrm{W} / \mathrm{m}^{2}$

$\rho \quad$ Air density.

$\mathrm{g} / \mathrm{m}^{3}$

Density of dry air.

$\mathrm{g} / \mathrm{m}^{3}$

$\rho_{\mathrm{d}} \quad$ Vapor density.

$\mathrm{g} / \mathrm{m}^{3}$

$\rho_{\mathrm{v}} \mathrm{a} \quad$ Ambient vapor density.

$\mathrm{g} / \mathrm{m}^{3}$

$\rho_{\mathrm{v}} \mathrm{s} \quad$ Saturated vapor density.

$\mathrm{g} / \mathrm{m}^{3}$

$\sigma \quad$ Stefan-Boltzmann constant. 


\title{
Measurement of Evapotranspiration in Phreatophyte Areas, Smith Creek Valley and Carson Desert, West-Central Nevada, 1983
}

\author{
By R.L. CARMAN
}

\begin{abstract}
Evaporation from bare soils and evapotranspiration from phreatophyte areas are major sources of natural groundwater loss in the Great Basin region of Nevada, Utah, and adjacent States. Many methods have been developed to try to quantify the amount of water used by phreatophytes and lost from bare soils. This study evaluated three of these methods for determining evapotranspiration under natural conditions and provides quantitative estimates of evapotranspiration. The methods used were (1) the eddy-correlation method, based on aerodynamics and turbulent transport; (2) the Bowen ratio method, based on an energy budget; and (3) the Penman method, based on aerodynamics and energy budgets. The eddy-correlation and Bowen ratio methods measure actual evapotranspiration under natural conditions, whereas the Penman method measures potential evapotranspiration. The two sites chosen for study were in Smith Creek Valley near Austin, Nev., and north of Soda Lake in the Carson Desert near Fallon, Nev.
\end{abstract}

Phreatophytes at the Smith Creek Valley site consist mainly of rabbitbrush. Actual evapotranspiration for 1983 at this site, estimated using the eddy-correlation method, was about 0.32 meter per year, whereas potential evapotranspiration, estimated by the Penman method, was about 2.0 meters per year. Phreatophytes at the Soda Lake site consist predominantly of greasewood. Actual evapotranspiration at this site for 1983, estimated by the eddy-correlation method, was 0.18 meter per year, whereas potential evapotranspiration, estimated by the Penman method, was 1.78 meters per year.

The high correlation of evapotranspiration with solar radiation may make it possible to estimate evapotranspiration in similar areas where solar or net-radiation data are available.

The methods and instrumentation systems used are accurate, relatively simple, and mobile, and they are effective in measuring evapotranspiration under natural conditions.

\section{INTRODUCTION}

\section{Background}

This evapotranspiration study is one of several studies that support the Regional Aquifer-Systems Analysis (RASA) program of the Great Basin region of Nevada, Utah, and adjacent States. These RASA studies are being conducted by the U.S. Geological Survey as part of a series of aquifer-system studies throughout the United States.

Ground water is a major source of water in the Great Basin. Therefore, determining the amount of water that becomes available through recharge and the amount that is lost through evapotranspiration (ET) is important for developing and administering ground-water resources in the Great Basin. The lack of quantitative field measurements of ET was recognized during the planning phase of the Great Basin RASA.

Phreatophytes are common plants in the lowlands of the Great Basin; these plants have the ability to tap ground water directly for their supply of water. In the Great Basin, ground water is lost primarily through transpiration by phreatophytes and evaporation from bare soils. Early estimates of ET were based on water-budget methods, empirical techniques, and meteorological techniques (Penman, 1948; Robinson, 1970; Hanson and Dawdy, 1976; Pennington, 1980). Technical advancements have facilitated such theoretical approaches for estimating ET as mass-transfer and energy-balance methods.

\section{Purpose and Scope}

The purpose of this study was to evaluate selected methods for estimating ET from areas of phreatophytes 
under natural conditions. Recently developed instrumentation was incorporated in the application and refinement of an eddy-correlation procedure to improve estimates of ET under natural conditions. This report presents these ET estimates and describes the methods used to obtain them. Results were analyzed to determine whether correlations exist between ET and physical or meteorological elements and to evaluate the possible transfer value of the results to similar sites.

Fieldwork began in April 1982 and continued through July 1984. Intensive field data collection began when the phreatophytes emerged from dormancy in the spring and ended when they returned to the dormant state in the fall. The fieldwork consisted of periodic water-level measurements in wells, continuous collection of meteorological data, periodic collection of heat-flux and temperature data, and some soil sampling. The 1982 field season was spent debugging the instrumentation and developing techniques. However, a large amount of data resulted from this study. Data collected during the 1983 season are the most accurate and complete and therefore are the only data discussed in this report.

\section{Acknowledgments}

E.P. Weeks and D.I. Stannard of the U.S. Geological Survey and Harold Weaver of Washington State University (Pullman) provided technical assistance.

\section{DESCRIPTION OF STUDY SITES}

Two sites in northern Nevada (fig. 1) were selected for study. The first site is north of Soda Lake in the Carson Desert and is approximately $14 \mathrm{~km}$ northwest of Fallon, Nev. The second site is in Smith Creek Valley and is approximately $40 \mathrm{~km}$ southwest of Austin, Nev. These sites were chosen primarily because they were considered to be representative of many phreatophyte areas in the northern Great Basin.

The Soda Lake site is in a desert region. The altitude of the site is approximately $1,220 \mathrm{~m}$ above sea level. Precipitation ranges from 15 to $20 \mathrm{~cm} / \mathrm{yr}$ and occurs principally as rainfall but includes some snow in the winter; total precipitation at this site during 1983 was $19.8 \mathrm{~cm}$. Temperatures range from -5 to $+30^{\circ} \mathrm{C}$ during the year; large daily temperature fluctuations are typical of northern Nevada. Total monthly precipitation and average monthly temperatures for 1983 are shown in figure 2.

Vegetation at the Soda Lake site consists mainly of greasewood (Sarcobatus vermiculatus), which covers approximately 5 percent of the area and has an average height of $1 \mathrm{~m}$. Predominant plant species also include shadscale (Atriplex confertifolia), bunchgrass, sagebrush (Artemisia tridentata), and saltcedar (Tamarix gallica). Approximately 82 percent of the area is bare soil. Depth to the water table is 7.5 to $9.0 \mathrm{~m}$. The soil is generally fine- to mediumgrained sand with some silt and clayey silt at depth. Areas of salt encrustation around ponded water near the Soda Lake site and stands of highly salt-tolerant saltcedar indicate high soil salinity. Greasewood is a moderately salt-tolerant shrub.

No surface-water runoff occurs at the Soda Lake site. Soil-moisture samples and water-level measurements taken near the site indicate that ground water is recharged locally by seepage from ponds and small lakes and by periods of intense rainfall (F.H. Olmsted, U.S. Geological Survey, oral commun., 1983).

The Smith Creek Valley site is in a semiarid basinplaya environment. The altitude of the site is about $1,844 \mathrm{~m}$. Precipitation, which occurs principally as snow and as summer thundershowers, ranges from 20 to $30 \mathrm{~cm} / \mathrm{yr}$ at this site; during 1983, precipitation was $29.5 \mathrm{~cm}$. Temperatures range from -11 to $29^{\circ} \mathrm{C}$. Total monthly precipitation and average monthly temperature data for 1983 are shown in figure 2.

Vegetation consists mainly of rabbitbrush (Chrysothamnus sp.), which covers about 25 percent of the area and has an average height of $0.9 \mathrm{~m}$. Great Basin wildrye (Elymus cinereus) is the other predominant species. Depth to the water table is 3 to $4.5 \mathrm{~m}$. Approximately 64 percent of the area is bare soil. The soil is dense, hard silty clay. Plant succession in Smith Creek Valley, typical of desert playas, is from bare playa to saltgrass (Distichlis stricta), to rabbitbrush, to rabbitbrush/greasewood or just greasewood and, finally, where the water table tends to be deeper than $4 \mathrm{~m}$, to sagebrush.

Surface-water runoff from surrounding mountains that reaches the playa evaporates or, during wet years, is a source of local ground-water recharge. Most ground water is recharged in the mountains, surrounding foothills, and alluvial fans.

A second study site near the main Smith Creek Valley site described above consists mostly of greasewood and little or no rabbitbrush. This site was chosen to obtain some additional (although sporadic) data to analyze the effect that different vegetation has on evapotranspiration.

\section{EVAPOTRANSPIRATION}

Evapotranspiration (ET), in general, is the combination of water consumptively used by plants through transpiration and water evaporated from bare soils. ET is generally referred to in terms of actual ET and potential ET, each of which can be further subdivided into total ET and net ET. Actual ET is the amount of water actually lost through ET under given conditions. Potential ET is the amount of water that could be lost through the process of ET if water availability is not a limiting factor. Total ET is the total amount of water used in the process of ET, regardless of the water's origin. Net ET is a component of total ET and, for the purposes of this study, can be defined as that part of total ET 


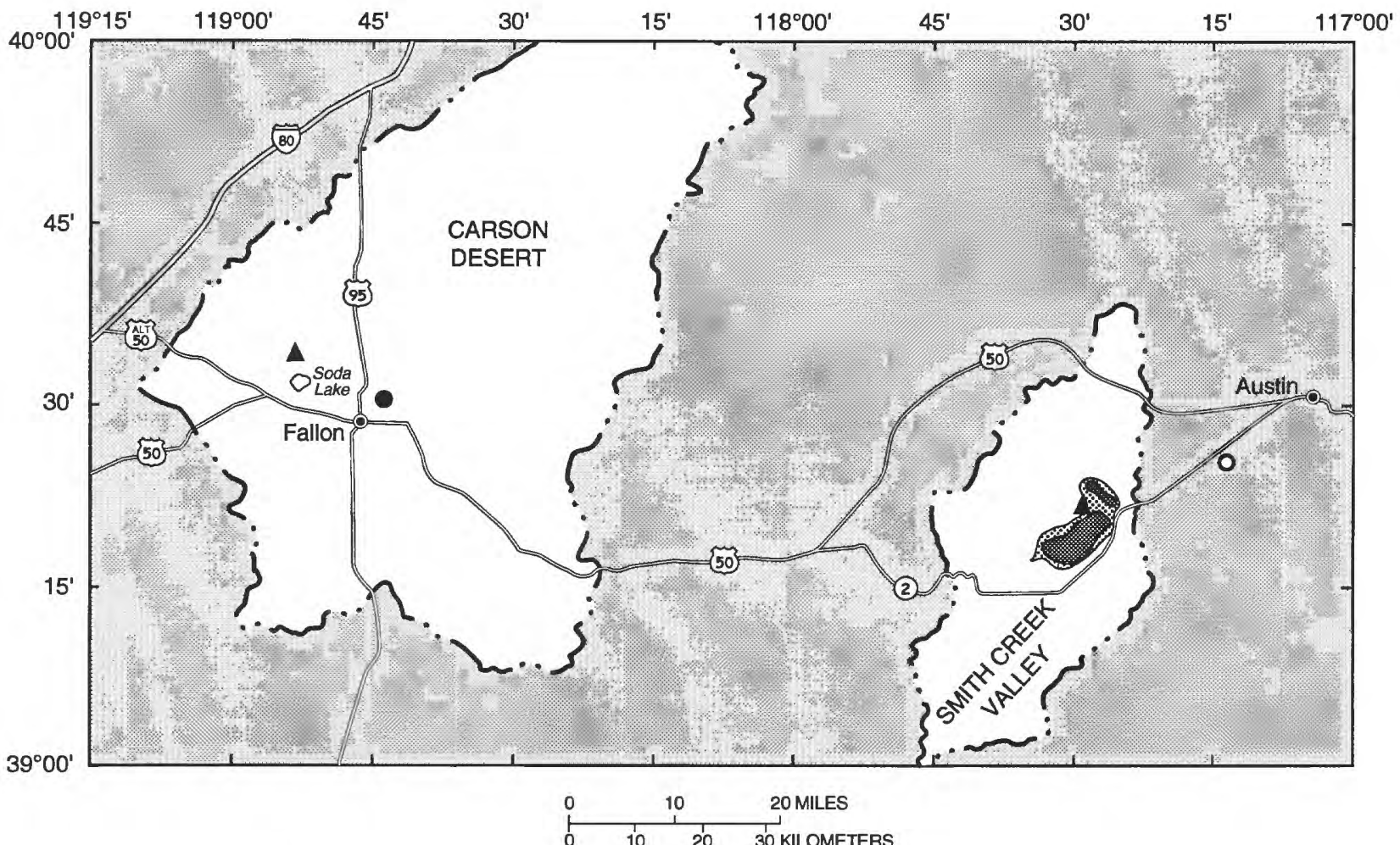

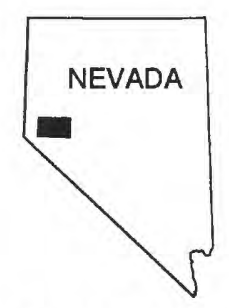

AREA OF MAP

Figure 1. Location of study sites.

derived from ground water. Net ET can be determined by subtracting precipitation and change in soil-moisture storage from total ET.

Net ET can be extremely difficult to determine, especially in recharge areas where precipitation percolates to the ground-water reservoir. To simplify matters, and because the main focus of this study was to evaluate the methodology, all values of ET are considered total ET and do not differentiate among soil moisture, precipitation, and ground water as sources of water for ET.

\section{Energy-Transport Mechanisms}

Eddy motion, or swirling of the air, is caused by mechanical and thermal, or convective, turbulence (fig. 3).
Mechanical turbulence is produced as wind moves over a surface and creates a drag. Thermal turbulence is produced as air is heated at the surface and is transported upward (Campbell, 1977, p. 33). Eddies are the transport mechanisms for heat, mass, and vapor to the atmosphere. The capacity of these eddies to transport heat or mass is directly related to the size of the vertical fluctuations (Campbell, 1977, p. 37). The farther from a surface, the larger the eddies become, and the larger the eddies, the more efficient the transport of heat and mass. Turbulent transport increases as wind speed, surface roughness, and surface heating increase.

The major source of energy for many of the processes in nature is net radiation. Photosynthesis and transpiration are closely tied to radiant energy (Campbell, 1977, p. 127). Where water availability is not a limiting factor, most of the 

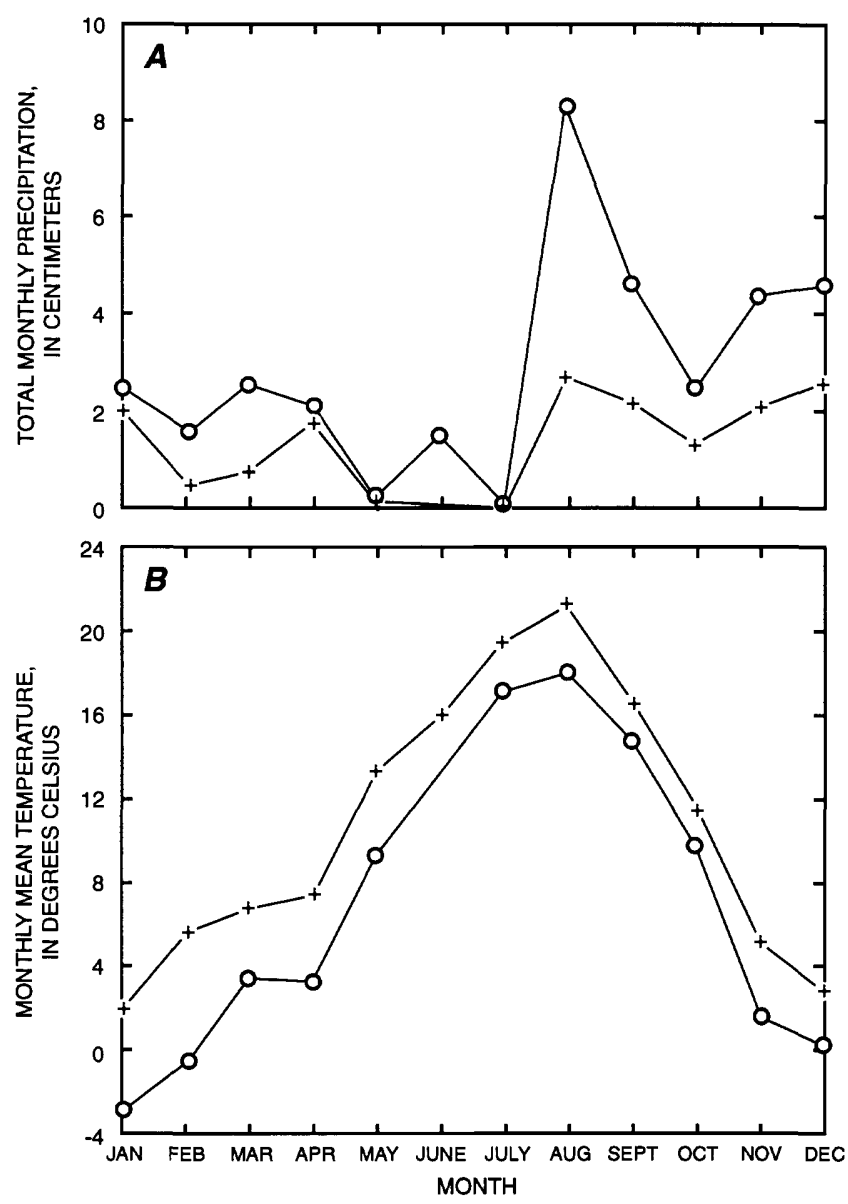

Figure 2. Climatological data for 1983 from Central Nevada Field Laboratory near Smith Creek Valley site (circles) and Fallon Experiment Station near Soda Lake site (crosses) (National Oceanic and Atmospheric Administration, 1983). No June data for Smith Creek Valley. $A$, Total monthly precipitation. $B$, Monthly mean air temperature.

energy supplied by net radiation is used for ET. Where water availability is a limiting factor, the residual radiant energy heats the soil and air (Hanks and Ashcroft, 1980, p. 101).

\section{Methods of Measurement}

The eddy-correlation, Bowen ratio, and Penman methods were used to evaluate ET at the two study sites. These methods are based on meteorologic measurements. The versatility and mobility of the instrumentation make these methods more desirable than previous methods that were based on the hydrologic cycle. Hanks and Ashcroft (1980) divided methods for determining ET into four major groups: aerodynamic methods, energy-budget methods, combined aerodynamic and energy-budget methods, and empirical methods.

The eddy-correlation method is an aerodynamic method and is based on turbulent-transport equations and measurement of atmospheric fluxes, or eddies. This method allows for estimation of evapotranspiration under natural conditions by using rapid-response instrumentation. Fastresponse high-frequency sensors measure vertical-wind, airtemperature, and vapor-density fluxes. Van Hylckama (1980, p. 13) stated that the eddy-correlation method is the only method that has the advantage of being "independent of the characteristics of the surfaces over which the measurements are made."

Two major energy fluxes can be determined with the eddy-correlation method: latent-heat flux, a function of vertical wind and vapor, and sensible-heat flux, a function of vertical wind and temperature. Latent-heat flux is the amount of energy required to convert water from a liquid to a vapor phase. Sensible-heat flux is the amount of energy that heats the air. A specific amount of latent energy can be associated with a specific mass of water; therefore, watervapor flux can be considered in terms of an equivalent amount of latent energy (Fritschen and Gay, 1979, p. 17). Vapor-flux density is determined from measurements of vapor density and vertical-wind velocity, then converted to an energy flux by multiplying by the latent heat of vaporization.

Sensible-heat flux is directly related to convective turbulence. When sensible-heat flux is positive (surface heating the air), the atmosphere is unstable and turbulence increases. When sensible-heat flux is negative (air warmer than surface), the atmosphere is stable and turbulence is suppressed by thermal stratification (Campbell, 1977, p. 41).

Other fluxes measured in conjunction with the eddycorrelation method are soil-heat flux and net radiation. Soilheat flux is the rate of heat transfer to the soil, or change in heat storage in the soil. Net radiation is the amount of incoming short- and long-wave radiation minus the outgoing short- and long-wave radiation. These additional values, combined with the sensible- and latent-heat fluxes measured by the eddy-correlation method, allow evaluation of the energy-balance, or energy-budget, equation.

An energy-budget equation may be expressed as "the heat input minus the heat loss equals the heat storage" (Campbell, 1977, p. 78). Evaluation of the energy budget provides a measure of the accuracy of the eddy-correlation method. The energy-budget equation as applied to this study is

$$
\lambda E+H=R_{\mathrm{n}}-G .
$$

The difference between the two sides of this equation, the energy-budget closure, indicates how efficient the system is in measuring latent- and sensible-heat fluxes. A nonzero energy-budget closure can be the result of instrument design problems, deterioration of the Lyman alpha hygrometer tubes, poor positioning of the instruments, or advection. The source of the discrepancy is difficult to determine. 


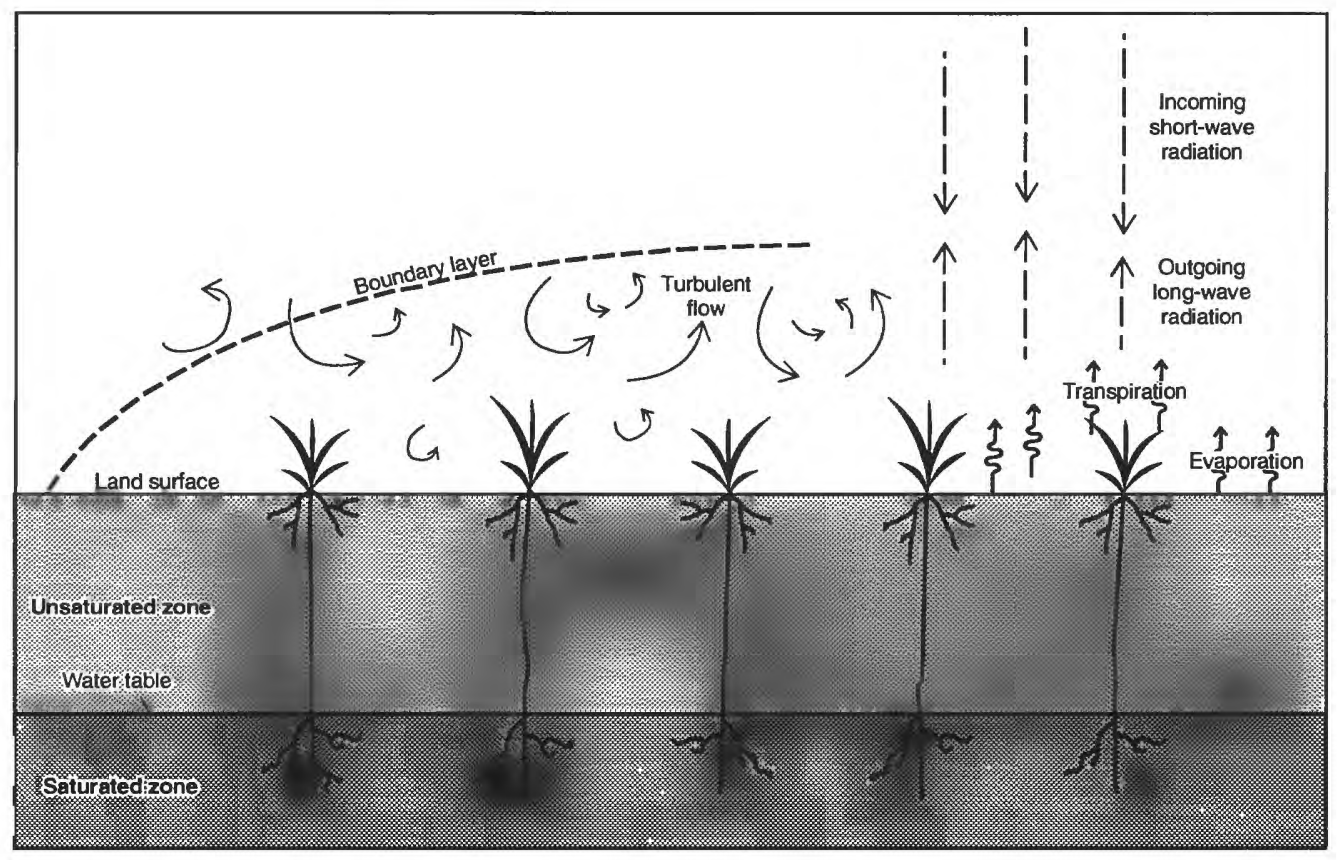

Figure 3. Processes involved in transport of heat and vapor into atmosphere.

The Bowen ratio method has been used extensively to estimate ET, and an attempt was made to use it in this study concurrently with the eddy-correlation method in order to compare results obtained from the two methods. The Bowen ratio method is based on the energy budget and is dependent on measurements of temperature and humidity gradients. The Bowen ratio, $H / E$, is the ratio of energy involved in the sensible heating of air to that involved in evaporating water (Schwerdtfeger, 1976, p. 54). The Bowen ratio method measures ET accurately when water availability is not a limiting factor so that sensible-heat flux and the Bowen ratio are small. When it is a limiting factor, the Bowen ratio and sensible-heat flux are large compared to latent-heat flux and introduce uncertainties into the calculated values of latentheat flux (Hanks and Ashcroft, 1980, p. 108).

The Penman method is a combination of aerodynamic and energy-budget methods and incorporates principles of both into the calculation of potential ET (Wilson and Rouse, 1971). The Penman method quantifies ET in terms of environmental parameters and diffusion resistances (Campbell, 1977, p. 120) and can be applied using data from most standard weather stations.

\section{Instrumentation}

Although the eddy-correlation method for determining actual ET had existed for some time, its implementation was not feasible on a routine basis because of the lack of highfrequency instrumentation to obtain necessary data. For accurate results, data must be collected about 10 times per second; this rate meant that the instrumentation had to have a fast response time. Another major problem was the large amount of data that had to be recorded, assimilated, and processed. Microprocessor-controlled data loggers enable high-frequency collection and recording of data.

Estimating ET by the eddy-correlation method requires measurement of vertical wind velocity, air temperature, vapor density, net radiation, and soil-heat flux. Instrumentation used to acquire these measurements is shown in figure 4.

The sonic anemometer, used to measure vertical wind velocity, has an accuracy of $\pm 5 \mathrm{~mm} / \mathrm{s}$ over a range of \pm 2.5 $\mathrm{m} / \mathrm{s}$. The anemometer consists of two vertical acoustical transducers. A sonic signal is alternated between the transducers, and velocity is determined by the phase shift of the signal caused by the wind. Connected to the sonic anemometer is a fine-wire $(0.001-\mathrm{cm})$ chromel-constantan thermocouple, which measures air-temperature fluxes. Both the sonic anemometer and fine-wire thermocouple transmit analog signals to a digital data logger.

A Lyman alpha hygrometer, consisting of a source tube and a detector tube (fig. 4), was used to measure fluctuations in vapor density. The source tube emits Lyman alpha radiation, which is intercepted by the detector tube, a nitric oxide ionization chamber. The radiation creates a current in the chamber that increases with the strength of radiation received. The strength of the current varies inversely with the vapor content of the air between the two tubes because Lyman alpha radiation has a high absorption coefficient for water vapor and is attenuated by moist air. 

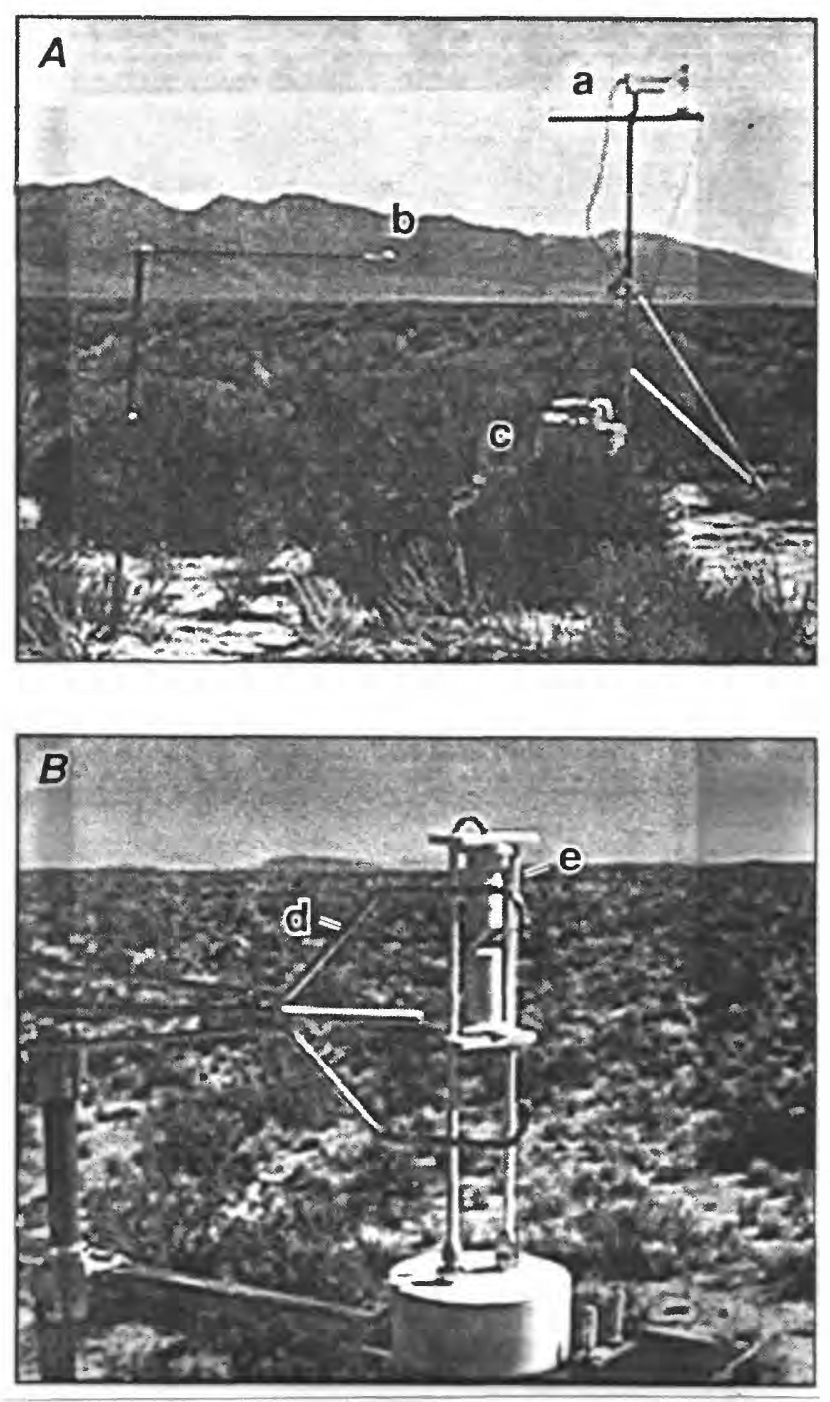

Figure 4. Eddy-correlation instrumentation at Soda Lake site, 1983. A, Overall view of sonic anemometer and Lyman alpha hygrometer (a), net radiometer (b), and data logger (c). B, Closeup view of sonic anemometer (d) and Lyman alpha hygrometer (e).

A modified, Fritschen-type net radiometer (fig. 4) with replaceable dome-shaped polyethylene windshields was used to measure net radiation. Specifications for the net radiometer are described by Fritschen and Gay (1979, p. 111).

Soil-heat flux was measured with thermoelectric ceramic modules manufactured by Melcor (Material Electronic Products Corporation, Trenton, N.J.). The soil-heatflux plate is made up of thermally conductive, metalized ceramic plates soldered to two heat-exchange surfaces.

A CR5 data logger (Campbell Scientific, Inc., Logan, Utah) was used to process and record eddy-correlation data. This small portable data logger is battery operated and computer compatible; it is able to record data on an audio cassette and has interchangeable input modules.
The data logger consists of a printer, a control module, an internal power supply, integrating millivolt and volt modules, and a microprocessor. The control module regulates the time and scan functions with a scan rate of 600 channels per minute. The millivolt integrating modules were used to obtain data from the net radiometer and soil-heatflux plates. The modules have a $\pm 0.2-\mathrm{mV}$ accuracy, depending on the ambient temperature, and have input resistances of $50 \mathrm{M} \Omega$ (Campbell Scientific, Inc., written commun., 1982). The K19 microprocessor was programmed to manipulate incoming data before recording it and was specially modified to scan at 10 cycles per second. Voltage-signal conditioner modules received and processed the analog voltages from the sonic anemometer, fine-wire thermocouple, and the Lyman alpha hygrometer. These modules provided integrated volt signals to the processor module for 0.1 -second intervals every other 0.1 second. Within the processor module, means of these integrated voltages and of the covariances of the sonic-anemometer with the fine-wire thermocouple voltages and of the sonic anemometer with the hygrometer voltages were recorded at 5-minute intervals and stored for the user-selected output interval. These stored values were output on a printer for immediate viewing and also were recorded on cassette tape for later transfer to a computer system.

When setting up the instrumentation in the field, several factors were considered: upwind fetch, height of the instruments, and instrument orientation relative to the prevailing wind direction. The fetch is the distance upwind from the instruments or length of uniform surface over which the wind has traveled (Campbell, 1977, p. 40). The fetch should be at least 100 times the height of the instrument in order to equilibrate the wind with the vegetated surface being studied and to avoid influences of upwind cover differing from that in the study area. Because the Lyman alpha hygrometer and sonic anemometer were placed at a height of approximately $3 \mathrm{~m}$, the instruments were set up in an area where there was at least $300 \mathrm{~m}$ of fetch upwind from the instruments. The instruments were set up facing into the prevailing wind to minimize interference by the instrument supports. The optimum instrument height of $3 \mathrm{~m}$ was determined from analysis of data from instruments placed at both $2 \mathrm{~m}$ and $3 \mathrm{~m}$ above the ground surface. Values from the 2-m height were consistently lower and the energy-budget closures were poorer than those from the 3-m height. At $2 \mathrm{~m}$, eddies were apparently too small, too rapid, or both, for the instruments to accurately measure the vertical component of flux (E.P. Weeks, U.S. Geological Survey, oral commun., 1982).

Compared with that of the other methods, instrumentation for the Bowen ratio method (fig. 5) was the simplest. The only data needed to determine ET for this method were air temperature and vapor density at two heights, net radiation, and soil-heat flux. Because net radiation and soil-heat flux already were being measured in conjunction with the 


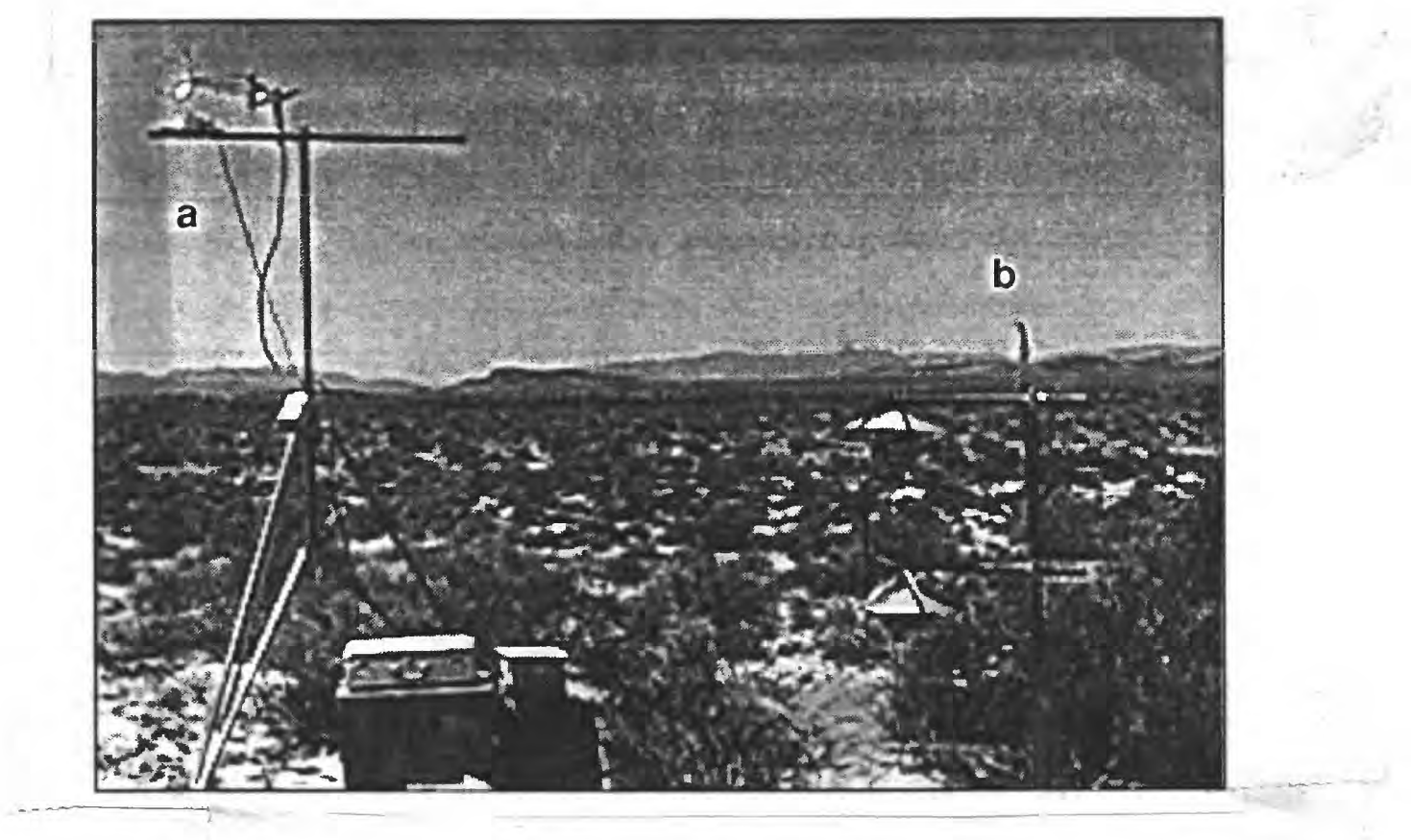

Figure 5. Bowen ratio instrumentation. Sonic anemometer and Lyman alpha hygrometer (a) and wet-bulb/dry-bulb psychrometer (b), Soda Lake site, 1983.

eddy-correlation system, only measurements of air temperature and vapor density were needed.

Small ventilated thermistor psychrometers were used to measure air temperature and vapor pressure (fig. 5). The psychrometers were used in conjunction with a CR21 data logger (discussed at the end of this section), which provides excitation and linearization of the readings. To obtain temperature and vapor-density profiles, one psychrometer was placed at the top of the vegetation canopy and the other was placed $1 \mathrm{~m}$ higher. Because the psychrometers were ventilated rather than aspirated, some errors may have been introduced during times of little or no wind. Systematic errors due to differences in calibration between the two psychrometers could have been eliminated by constructing a system whereby they could be interchanged periodically.

The parameters needed to determine ET by the Penman method are wind speed, relative humidity or vapor density, soil-heat flux, net radiation or solar radiation, and air temperature. Instrumentation for a typical Penman weather station is shown in figure 6.

A Met-One wind-speed sensor (a three-cup anemometer with a magnetic reed-switch assembly) was used to measure wind velocity. The frequency of contact closures is proportional to wind velocity. The sensor is accurate to within \pm 1.5 percent or $\pm 0.11 \mathrm{~m} / \mathrm{s}$, has a range of 0 to $50 \mathrm{~m} / \mathrm{s}$, and has a distance constant of less than $4.6 \mathrm{~m}$. It delivers a pulsed output and can be used in conjunction with both digital and analog systems.

The relative-humidity sensor contains a Phys-Chemical Research Model PCRC-11 relative-humidity probe
( \pm 1 -percent deviation), which is a sulfonated-polystyrene plate with a Fenwal thermistor attached to measure air temperature. The relative-humidity sensor is linear to within \pm 3 percent when relative humidity is 10 to 97 percent (Campbell Scientific, Inc., written commun., 1983).

Soil-heat flux was determined with soil-heat-flux plates as described previously for the eddy-correlation method. Solar radiation was measured using a silicon pyranometer, which consists of a silicon photodiode sensor, which measures global radiation. Sensor output is in $\mu \mathrm{V} / \mathrm{W} / \mathrm{m}^{2}$. Calibration factors were provided by the supplier or were obtained by calibrating against an Eppley precision pyranometer. The uncertainty of the calibration is \pm 5 percent.

A battery-operated micrologger (a programmable CR21 data logger) processed and recorded data from the Penman instrumentation. Data from the micrologger can be recorded to cassette tape or printer tape. The micrologger contains a microcomputer and has nine input channelsseven analog and two pulse-counting. The micrologger scans inputs every 10 or 60 seconds, depending on the model. Amplifier accuracy is \pm 0.2 percent in the temperature range 0 to $40^{\circ} \mathrm{C}$. Resolution is $\pm 5 \mu \mathrm{V}$ in the millivolt range and $\pm 1 \mathrm{mV}$ in the volt range.

\section{Equations for Calculating Evapotranspiration}

Latent-heat flux is computed from the CR5 output by the following equation (Campbell Scientific, Inc., written commun., 1982): 

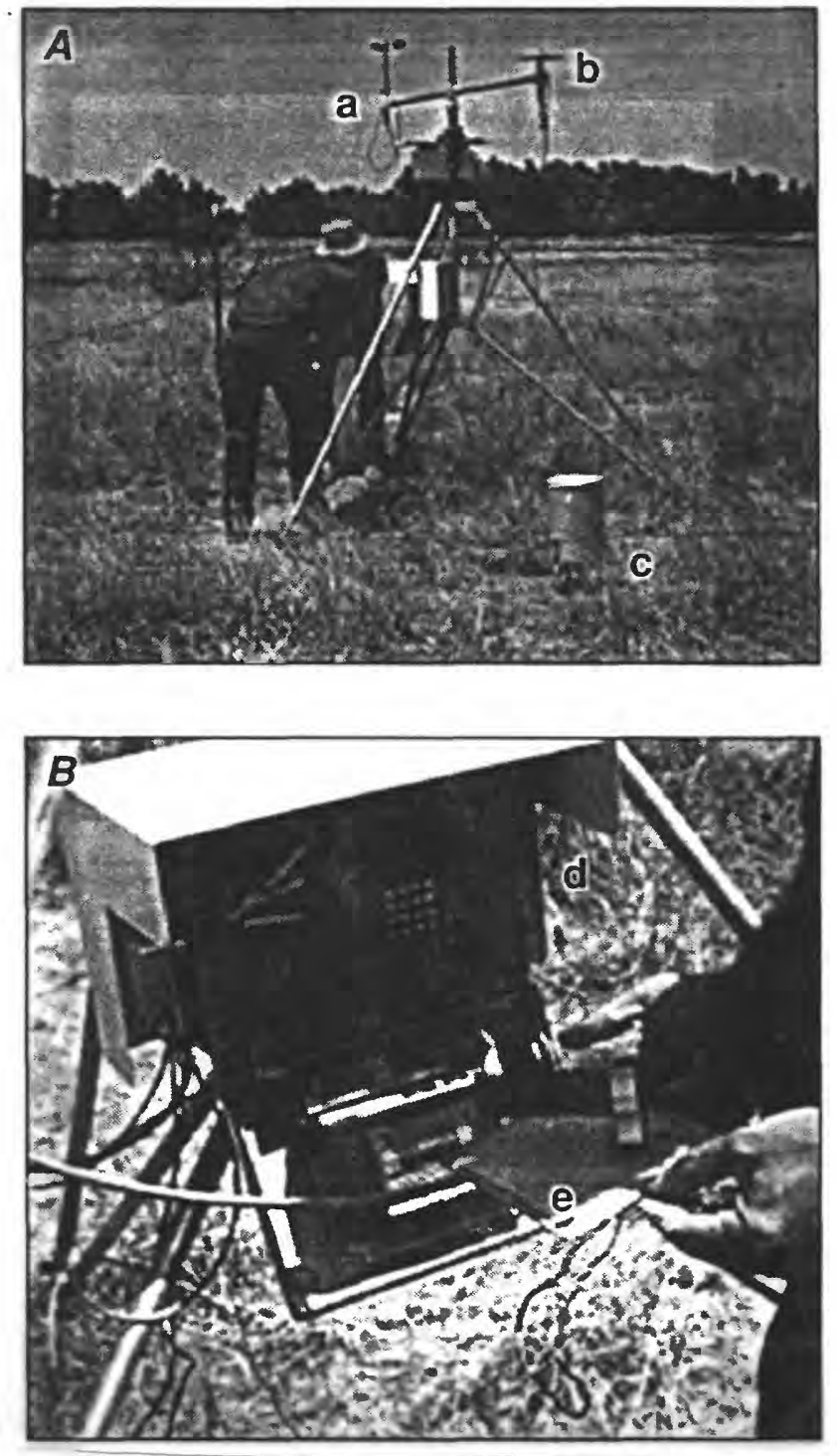

Figure 6. Penman weather-station instrumentation (near Artesia, N. Mex., 1983). A, Overall view of cup anemometer (a), silicon pyranometer (b), and tipping-bucket rain gage (c). B, Closeup view of CR21 micrologger (d) and relative-humidity probe (e).

$$
\lambda E=\frac{C_{\mathrm{s}} \lambda\left(C_{\rho_{\mathrm{v}} \mathrm{u}}\right)}{100\left(a+2 b \rho_{\mathrm{v}}\right)},
$$

where $\lambda \cong 2,450 \mathrm{~J} / \mathrm{g}$, and

$$
C_{\mathrm{s}}=0.005 \mathrm{~m} / \mathrm{s} / \text { count. }
$$

Sensible-heat flux is computed from the CR5 output by the following equation (Campbell Scientific, Inc., written commun., 1982):

$$
H=4 C_{\mathrm{v}_{1} \mathrm{v}_{2}} C_{\mathrm{s}} C_{\mathrm{f}} \rho C_{\mathrm{p}}
$$

where 4 compensates for attenuation factor of data logger,

$$
\begin{aligned}
& C_{\mathrm{s}}=0.005 \mathrm{~m} / \mathrm{s} / \text { count, } \\
& C_{\mathrm{f}}=0.02^{\circ} \mathrm{C} \text {, and } \\
& C_{\mathrm{p}} \cong 1.01 \mathrm{~J} / \mathrm{g} /{ }^{\circ} \mathrm{C} \text {. }
\end{aligned}
$$

Air density can be approximated by the following equation (E.P. Weeks, U.S. Geological Survey, written commun., 1981):

$$
\rho=\rho_{\mathrm{d}} \mathrm{e}^{-\mathrm{A} / 8,400} T_{\mathrm{a}} / 273.15,
$$

where $\rho_{\mathrm{d}}=1,292 \mathrm{~g} / \mathrm{m}^{3}$;

$-\mathrm{A} / 8,400=$ approximate ratio of station pressure to standard pressure (dimensionless); and

273.15 = solid-liquid equilibrium temperature for water, in kelvins $\left(273.15 \mathrm{~K}=0^{\circ} \mathrm{C}\right)$.

Equations 2 and 3 use the covariances from the data logger to compute the flux terms. Eddy-correlation equations for latent- and sensible-heat flux were discussed in detail by Van Hylckama (1980), Campbell (1977), and others.

The equation used to calculate ET by the Bowen ratio method (Wilson and Rouse, 1971, p. 437; Campbell, 1977, p. 136) is as follows:

$$
\beta=\gamma\left(\Delta t_{\mathrm{z}} / \Delta \rho_{\mathrm{v}}\right)\left(r_{\mathrm{v}} / r_{\mathrm{h}}\right)=\frac{\rho C_{\mathrm{p}} \Delta t_{\mathrm{z}}}{\lambda \Delta \rho_{\mathrm{v}}},
$$

where $C_{\mathrm{p}}=1.01 \mathrm{~J} / \mathrm{g} /{ }^{\circ} \mathrm{C}$,

$\Delta t_{\mathrm{z}}=$ air-temperature difference between instruments at different heights, in degrees Celsius; and

$\Delta \rho_{\mathrm{v}}=$ vapor-density difference between instruments at different heights, in grams per cubic meter.

Note that because $r_{\mathrm{v}}$ and $r_{\mathrm{h}}$ are assumed to be equal, $r_{\mathrm{v}} / r_{\mathrm{h}}=1$.

The collection of net-radiation and soil-heat-flux data allows the calculation of latent-heat flux, as follows:

$$
\lambda E=\frac{R_{\mathrm{n}}-G}{1+\beta} .
$$

The three Penman equations, 7, 8, and 9, used to calculate potential ET for crops and bare soils (Campbell, 1977, p. 38-39, 137-138) are as follows: 


$$
\begin{gathered}
\lambda E=\frac{S\left(R_{\mathrm{n}}-G\right)+\frac{\rho C_{\mathrm{p}}\left(\rho_{\mathrm{v}_{\mathrm{s}}}-\rho_{\mathrm{v}_{a}}\right)}{r_{\mathrm{h}}}}{\gamma^{*}+S}, \\
\gamma^{*}=\gamma r_{\mathrm{v}} / r_{\mathrm{h}},
\end{gathered}
$$

and

$$
r_{\mathrm{h}}=\frac{\ln \left[\left(Z-d+z_{\mathrm{h}}\right) / Z_{\mathrm{h}}\right] \ln \left[\left(Z-d+z_{\mathrm{m}}\right) / z_{\mathrm{m}}\right]}{k^{2} u},
$$

where $d=0.64 h \mathrm{~m}$,

$$
\begin{aligned}
z_{\mathrm{h}} & =0.26 h, \\
z_{\mathrm{m}} & =0.13 h, \text { and } \\
k & \cong 0.4 \text { (dimensionless). }
\end{aligned}
$$

The equation used to convert solar radiation to net radiation (modified from Brutsaert, 1982, eq. 6.2, p. 131) is as follows:

$$
R_{\mathrm{n}}=R_{\mathrm{s}}\left(1-\alpha_{\mathrm{s}}\right)+\varepsilon_{\mathrm{s}} R_{\mathrm{l}_{\mathrm{d}}}-R_{\mathrm{l}_{\mathrm{u}}}=R_{\mathrm{s}}\left(1-\alpha_{\mathrm{s}}\right)+L_{\mathrm{n}},
$$

where $\alpha_{s} \cong 0.25$ to 0.28 (dimensionless), and

$$
\varepsilon_{\mathrm{s}} \cong 0.97 \text { (dimensionless). }
$$

The net long-wave radiation $\left(L_{\mathrm{n}}\right)$ also can be calculated by the following equation (Campbell, 1977, p. 139):

$$
L_{\mathrm{n}}=\left(\varepsilon_{\mathrm{a}}-\varepsilon_{\mathrm{s}}\right) \sigma T_{\mathrm{a}}^{4},
$$

where $\varepsilon_{\mathrm{a}}=0.72+0.005 T$ (dimensionless) (Campbell, 1977, p. 58),

$\varepsilon_{\mathrm{s}} \cong 0.97$ (dimensionless), and $\sigma=5.67 \times 10^{-8} \mathrm{~W} / \mathrm{m}^{2} / T_{\mathrm{a}}^{4}$.

\section{DATA SUMMARY}

The eddy-correlation instrumentation measures flux values (for determining sensible- and latent-heat flux) as well as other components of the energy budget. These values were integrated and recorded every 30 minutes. Total ET and ET rates were calculated from the latent-heat-flux values. The data for each day were compiled to determine daily total and average values. The average of the daily totals was determined and multiplied by 180 (the approximate number of days for the active growing season) to estimate annual ET. Although the 30 -minute values illustrate fluctuations of the various components, daily values, particularly for soil-heat flux, integrated over a 24-hour period are more reliable because of problems and uncertainties associated with the system.

The Bowen ratio method provides only total daily values for ET determined by integrating data collected at 30minute intervals over a period of 24 hours. The average of the daily totals was determined and multiplied by 180 to estimate total annual ET.

The Penman method provides estimates of potential ET and associated meteorological parameters from data integrated over a period of 60 minutes. These values were manipulated in the same way as the eddy-correlation data to provide values of daily total and average potential ET and an average of the daily totals for estimating annual potential ET.

Intermittent daily data obtained by the eddy-correlation method are available for both study sites beginning with the onset of new growth (April 1983) until dormancy began (in October). A limited amount of Bowen ratio data are available for the Smith Creek Valley site for the period June to September. As a result of mechanical and technical problems, mainly caused by strong, gusty winds and blowing sand, only 2 days of Bowen ratio data are available for the Soda Lake site. Essentially continuous meteorological data were obtained from the Penman weather stations for the period January to December 1983.

ET data determined by the three methods at each study site are shown in tables 1 and 2. Pan-evaporation data collected from the Fallon Experiment Station and the Central Nevada Field Laboratory in Reese River Valley (near Smith Creek Valley) are included for comparison with the Penman data. Pan-evaporation data from the station in the Reese River Valley were unavailable for most days.

Typical hourly fluctuations in sensible- and latent-heat fluxes, soil-heat flux, and net radiation determined by the eddy-correlation method are shown in figure 7. During daylight hours, particularly midday, sensible-heat flux exceeded latent-heat flux because the limited ability of the plant to transpire water created an excess of available energy. If water availability had not been a limiting factor, much of the radiant energy would have been used in evaporation and transpiration. The energy-budget closure for each day is also shown in figure 7. The closure deficit is greatest for the Soda Lake site.

The period May 31 to June 5 was a time of heavy precipitation. As a result, the Penman data curves reflect a dramatic decrease in potential ET. Unfortunately, the instrumentation for the eddy-correlation method has a tendency to short-circuit when exposed to heavy moisture, so, except for June 1 at the Smith Creek Valley site, no data for actual ET are available for this period. 
Table 1. Evapotranspiration determined by different methods for selected days during 1983 in Smith Creek Valley and vicinity

$[--$, no data avalable $]$

\begin{tabular}{|c|c|c|c|c|c|}
\hline \multirow{3}{*}{ Date } & \multicolumn{5}{|c|}{$\begin{array}{l}\text { Evapotranspiration } \\
\text { (centimeters per day) }\end{array}$} \\
\hline & \multicolumn{2}{|c|}{ Eddy-correlation ${ }^{1}$ method } & \multirow{2}{*}{$\begin{array}{l}\text { Bowen ratio } \\
\text { method }\end{array}$} & \multirow{2}{*}{$\begin{array}{l}\text { Penman } \\
\text { method }\end{array}$} & \multirow{2}{*}{$\begin{array}{c}\text { Pan- } \\
\text { evaporation }{ }^{2} \\
\text { method }\end{array}$} \\
\hline & Rabbitbrush & Greasewood & & & \\
\hline \multicolumn{6}{|c|}{ April 1983} \\
\hline $27 \ldots \ldots$ & 0.156 & -- & -- & 0.99 & -- \\
\hline $28 \ldots \ldots$ & .283 & -- & -- & 1.11 & -- \\
\hline \multicolumn{6}{|c|}{ May 1983} \\
\hline $31 \ldots \ldots$ & -- & -- & -- & 1.73 & 0.91 \\
\hline \multicolumn{6}{|c|}{ June 1983} \\
\hline $1 \ldots \ldots$ & 0.079 & -- & -- & 0.98 & -- \\
\hline $2 \ldots \ldots$ & -- & -- & -- & .82 & -- \\
\hline $3 \ldots \ldots$ & -- & - & -- & .91 & -- \\
\hline $4 \ldots \ldots$ & -- & -- & -- & .79 & -- \\
\hline $5 \ldots \ldots$ & -- & -- & -- & 1.25 & -- \\
\hline $28 \ldots \ldots$ & .421 & -- & 0.035 & 1.50 & 0.86 \\
\hline $29 \ldots \ldots$ & .403 & -- & -- & 1.62 & .94 \\
\hline $30 \ldots \ldots$ & .340 & -- & .33 & 1.51 & .84 \\
\hline \multicolumn{6}{|c|}{ September 1983} \\
\hline $14 \ldots \ldots$ & 0.101 & -- & -- & 0.94 & -- \\
\hline $15 \ldots \ldots$ & .104 & -- & 0.27 & .84 & -- \\
\hline $16 \ldots \ldots$ & .097 & 0.054 & .26 & .98 & -- \\
\hline $17 \ldots \ldots$ & .098 & .095 & .27 & 1.10 & -- \\
\hline $18 \ldots \ldots$ & .125 & .099 & .27 & 1.26 & -- \\
\hline $19 \ldots \ldots$ & .069 & $3^{.040}$ & .26 & .99 & -- \\
\hline $20 \ldots \ldots$ & .073 & .024 & .31 & .70 & -- \\
\hline
\end{tabular}

\footnotetext{
${ }^{1}$ Data from Smith Creek Valley.

${ }^{2}$ Data, from Reese River Valley, collected by Central Nevada Field Laboratory (National Oceanic and Atmospheric Administration, 1983).

${ }^{3}$ Total for 12 hours only.
}

Hourly data collected from the Penman weather stations for the period May 31 to June 5 are shown in figure 8. Solar-radiation data for the Soda Lake site for May 31 produced a smooth curve, which indicates a cloudless day. Curves for relative humidity and temperature are also relatively smooth. Summer thunderstorms occurred from approximately June 1 to June 4 at both sites. Total precipitation for this period was $2.0 \mathrm{~cm}$ in Smith Creek Valley and $1.6 \mathrm{~cm}$ at Soda Lake. Wind, vapor density, relative humidity, and solar radiation were very erratic throughout this period. During the precipitation, potential ET decreased by 40 to 50 percent and recovered slowly after precipitation ceased. On June 5, potential ET was still much lower than on May 31, the cloudless day preceding the precipitation.
The eddy-correlation and Penman data curves shown in figure 9 reflect seasonal variations in actual and potential ET, respectively. Seasonal variations are indicated also by pan-evaporation data from the Fallon Experiment Station. The pan-evaporation data were obtained from weather stations maintained by the University of Nevada, Reno, and were published by the National Oceanic and Atmospheric Administration (1983). Pan evaporation should approximate potential ET. Pan-evaporation values are lower than computed potential-ET values, possibly due to the weather stations' being situated in areas of irrigated fields, which would tend to increase the relative humidity or vapor density of the air and thereby decrease the vapor-density gradient and the amount of evaporation. 
Table 2. Evapotranspiration determined by different methods for selected days during 1983 near Soda Lake

[Pan-evaporation data from Fallon experiment Station (National Oceanic and Atmospheric Administration, 1983). --, no data available]

\begin{tabular}{|c|c|c|c|c|}
\hline \multirow{2}{*}{ Date } & \multicolumn{4}{|c|}{$\begin{array}{l}\text { Evapotranspiration } \\
\text { (centimeters per day) }\end{array}$} \\
\hline & $\begin{array}{l}\text { Eddy- } \\
\text { correlation } \\
\text { method }\end{array}$ & $\begin{array}{l}\text { Bowen ratio } \\
\text { method }\end{array}$ & $\begin{array}{l}\text { Penman } \\
\text { method }\end{array}$ & $\begin{array}{c}\text { Pan- } \\
\text { evaporation } \\
\text { method }\end{array}$ \\
\hline \multicolumn{5}{|c|}{ April 1983} \\
\hline $13 \ldots \ldots$ & -- & -- & 0.617 & 0.30 \\
\hline $21 \ldots \ldots$ & 0.105 & -- & -- & .30 \\
\hline \multicolumn{5}{|c|}{ May 1983} \\
\hline $31 \ldots$ & -- & -- & 1.506 & 0.58 \\
\hline \multicolumn{5}{|c|}{ June 1983} \\
\hline $1 \ldots$ & -- & -- & 0.652 & -- \\
\hline $2 \ldots \ldots$ & -- & -- & .656 & 0.53 \\
\hline $3 \ldots$ & -- & -- & .665 & .25 \\
\hline & ${ }^{1} 0.271$ & -- & .677 & .56 \\
\hline $5 \ldots$ & -- & -- & .937 & .38 \\
\hline \multicolumn{5}{|c|}{ July 1983} \\
\hline $6 \ldots$ & .130 & -- & 1.572 & 1.52 \\
\hline $7 \ldots$ & .134 & -- & 1.566 & 1.32 \\
\hline \multicolumn{5}{|c|}{ August 1983} \\
\hline $2 \ldots$ & 0.072 & -- & 1.336 & 0.91 \\
\hline $3 \ldots$ & .076 & -- & 1.246 & .94 \\
\hline $31 \ldots$ & .039 & 0.19 & 1.230 & .69 \\
\hline \multicolumn{5}{|c|}{ September 1983} \\
\hline $1 \ldots$ & 0.021 & -- & 1.028 & 0.58 \\
\hline $27 \ldots \ldots$ & .210 & 0.17 & .720 & .28 \\
\hline $29 \ldots \ldots$ & -- & .090 & .424 & .10 \\
\hline
\end{tabular}

${ }^{1}$ Total for 12 hours only.

In Smith Creek Valley, eddy-correlation measurements were taken in two areas, one covered predominantly by rabbitbrush and another by greasewood. Results of these measurements are compared in figure 10 . The ET values for rabbitbrush were consistently higher than those for greasewood. The two sites, which are less than $800 \mathrm{~m}$ apart, had mature stands of vegetation, but the rabbitbrush appeared much larger and more vigorous than the greasewood. Also, the greasewood seemed to emerge from winter dormancy later and become dormant earlier in the fall than the rabbitbrush.
Total ET during the 1983 active growing season (approx. 180 days) was estimated from daily averages obtained by each of the methods (tables 2 and 3). Pan-evaporation data is included for comparison.

Some problems arose during measurement of latentheat flux. The energy-budget closure often showed a large deficit, and the Lyman alpha hygrometer used to measure vertical vapor flux malfunctioned. The performance of the source and detector tubes in the Lyman alpha hygrometer deteriorated over a period of time. E.P. Weeks and D.I. Stannard (U.S. Geological Survey, oral commun., 1983) 


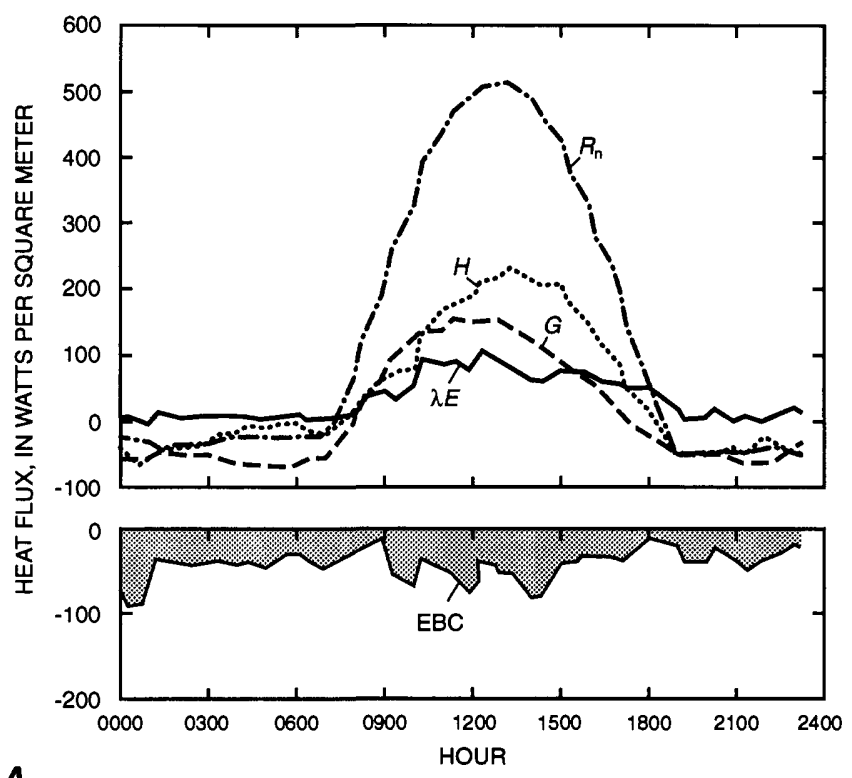

A

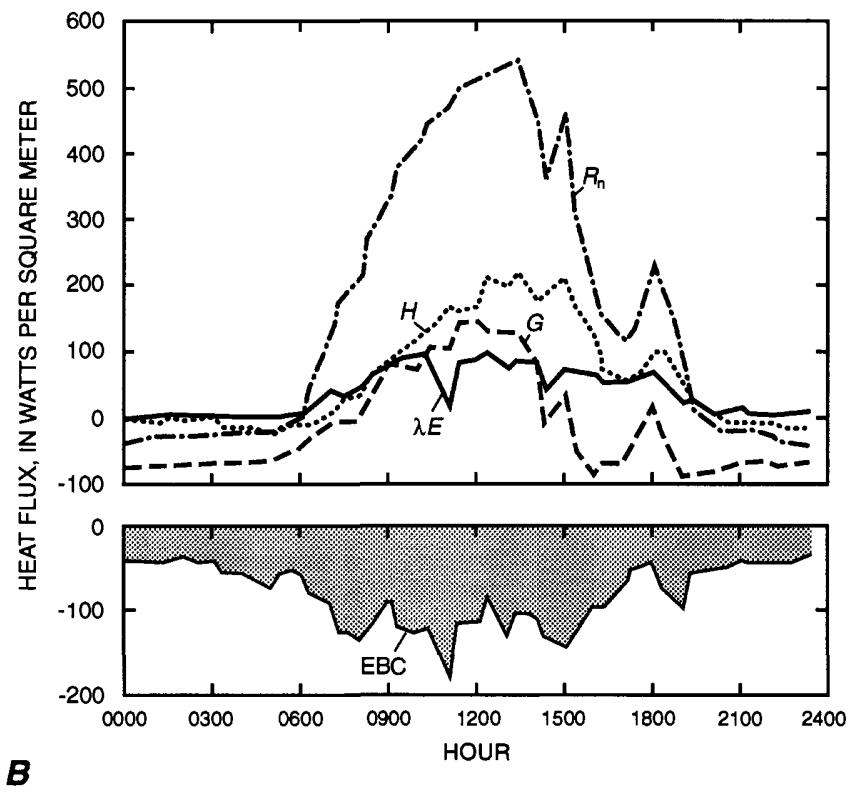

Figure 7. Heat flux determined by eddy-correlation method. $A$, Smith Creek Valley site, September 18, 1983 (total $E T=$ $0.12 \mathrm{~cm}$ ). $B$, Soda Lake site, July 7,1983 (total $E T=0.13 \mathrm{~cm}$ ). $E B C$, energy-budget closure; $G$, soil-heat flux; $H$, sensibleheat flux; $R_{n}$, net radiation; $\lambda E$, latent-heat flux.

suggested using a residual, or calculated, latent-heat flux along with or instead of a measured latent-heat flux. E.P. Weeks (written commun., 1985) also suggested that the measured and residual latent-heat-flux values represent the lower and upper boundaries, respectively, that bracket the actual latent-heat-flux values. Sensible-heat flux, soil-heatflux, and net-radiation values, derived from field measurements, are used in the energy-budget equation (eq. 1) to determine latent-heat flux as a residual. This method does not allow determination of the energy-budget closure but does provide an alternative to using the Lyman alpha hygrometer to determine latent-heat flux.

ET values derived from measured and residual values of latent-heat flux are shown in figures 11 and 12 and in table 3. Average measured ET $(\sim 0.18 \mathrm{~cm} / \mathrm{d}$ or $0.66 \mathrm{~m} / \mathrm{yr})$ correlates well with average residual ET $(\sim 0.23 \mathrm{~cm} / \mathrm{d}$ or 0.84 $\mathrm{m} / \mathrm{yr}$ ) for the Smith Creek Valley site, whereas the correlation for the Soda Lake site is low. ET values measured at the Soda Lake site during 1983 averaged $0.10 \mathrm{~cm} / \mathrm{d}$ or $0.37 \mathrm{~m} / \mathrm{yr}$. The residual-ET values for the Soda Lake site for 1983 averaged about $0.16 \mathrm{~cm} / \mathrm{d}$ or $0.58 \mathrm{~m} / \mathrm{yr}$.

An example of measured and residual latent-heat flux on an hourly basis for the Smith Creek Valley site is shown in figure 12. The area between the two curves shows the range of actual ET values.

\section{Correlations}

Of the values measured by both the Penman and eddycorrelation methods, the best correlations were between ET and solar radiation and between ET and net radiation-as was found in many previous studies. Jensen and Haise (1963) suggested using the ratio of ET to solar radiation or ET to net radiation as a basis for predicting ET. This ratio would represent the combined effects of reflectance, net thermal radiation, sensible-heat flux, soil-heat flux, and other minor components. Also, it may be possible to estimate ET for periods of time when no data were collected by using a ratio of actual to potential ET. Campbell (1977, p. 141) indicated that this was not a feasible method for estimating ET: "ET is not functionally related to potential ET" because, when water availability is a limiting factor, the rate of water loss is controlled by the soil-plant system rather than by atmospheric factors. However, if the phreatophytes derive their water directly from ground-water storage, then atmospheric factors would continue to control water loss.

Regression analysis showed that the correlation coefficients for ET and solar radiation were 0.8 or higher; most of the coefficients were 0.9 or higher. Results typical of regression analyses for data collected at both sites are plotted in figure 13. The data used for the example analysis are from the Penman weather station at the Smith Creek Valley site; similar results were obtained by using data from the Penman weather station at Soda Lake. Analyses of the eddy-correlation data (latent-heat flux and net radiation) from both sites also yielded similar results. The $r^{2}$ values (fig. 13), called coefficients of determination, indicate the proportion of the total variation of one variable that can be attributed to the relation with another variable (Freund, 1973, p. 421). The square root of the coefficient of determination is the correlation coefficient $(r)$ and is a "measure of the strength of the linear relationship between two variables" (Freund, 1973, p. 422). When $r=0$, no linear relation exists; when $r= \pm 1$, a 

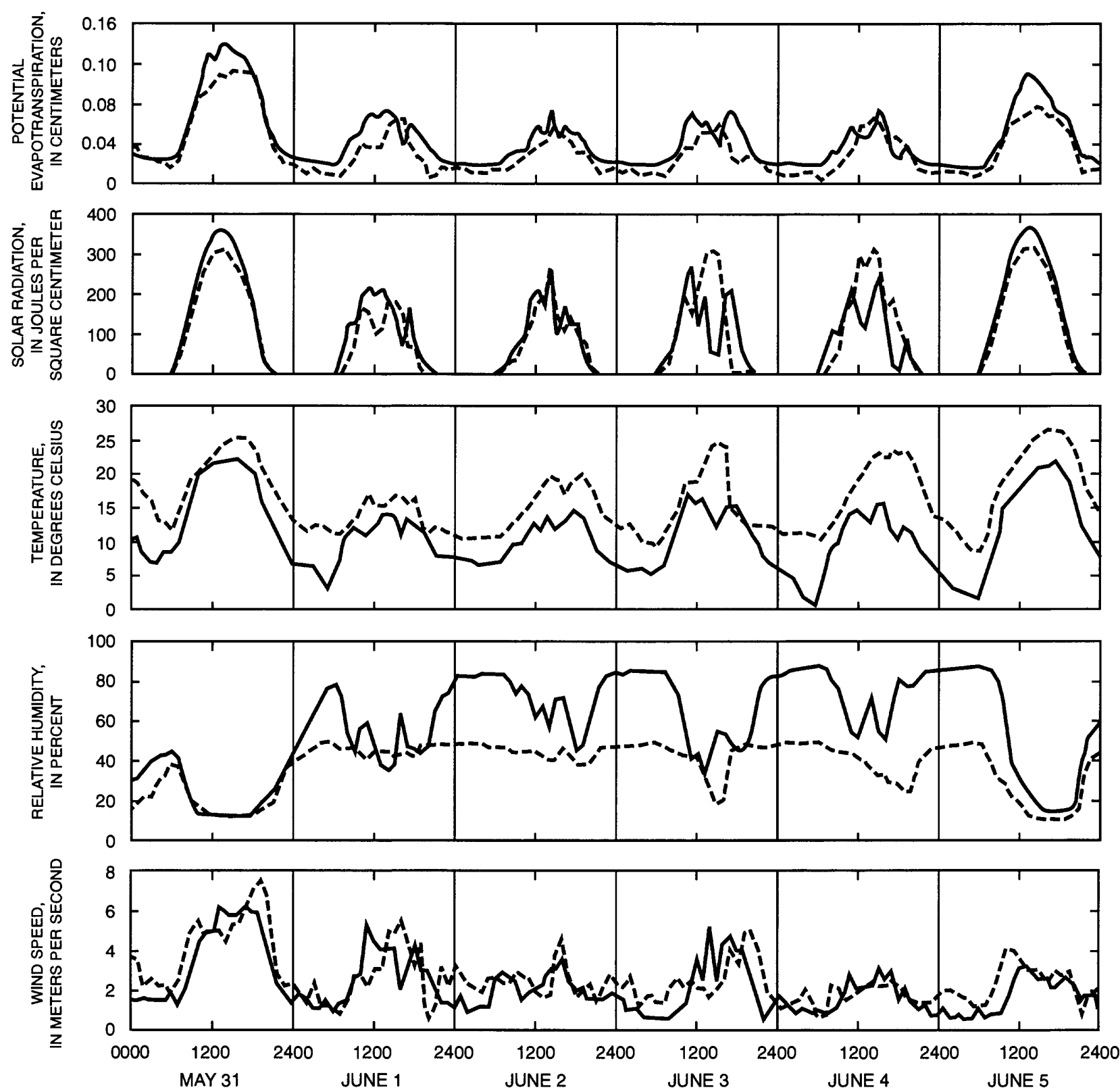

DATE AND HOUR

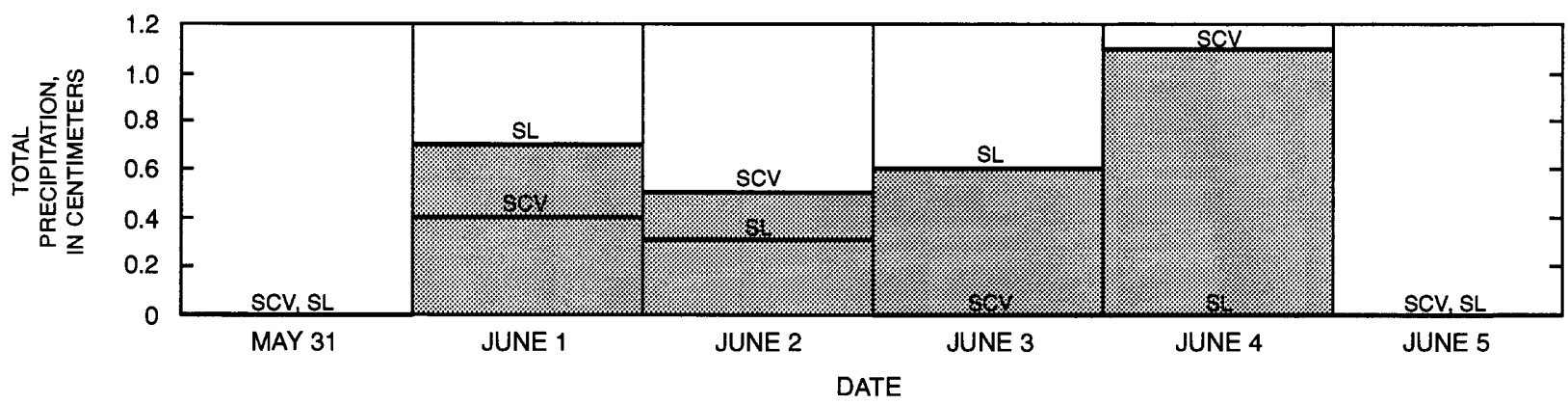

Figure 8. Potential-evapotranspiration values and Penman weather-station data, showing effects of inclement weather for period May 31, 1983, through June 5, 1983. Data for Smith Creek Valley site (SCV) shown as solid line; data for Soda Lake site (SL) shown as dashed line. 


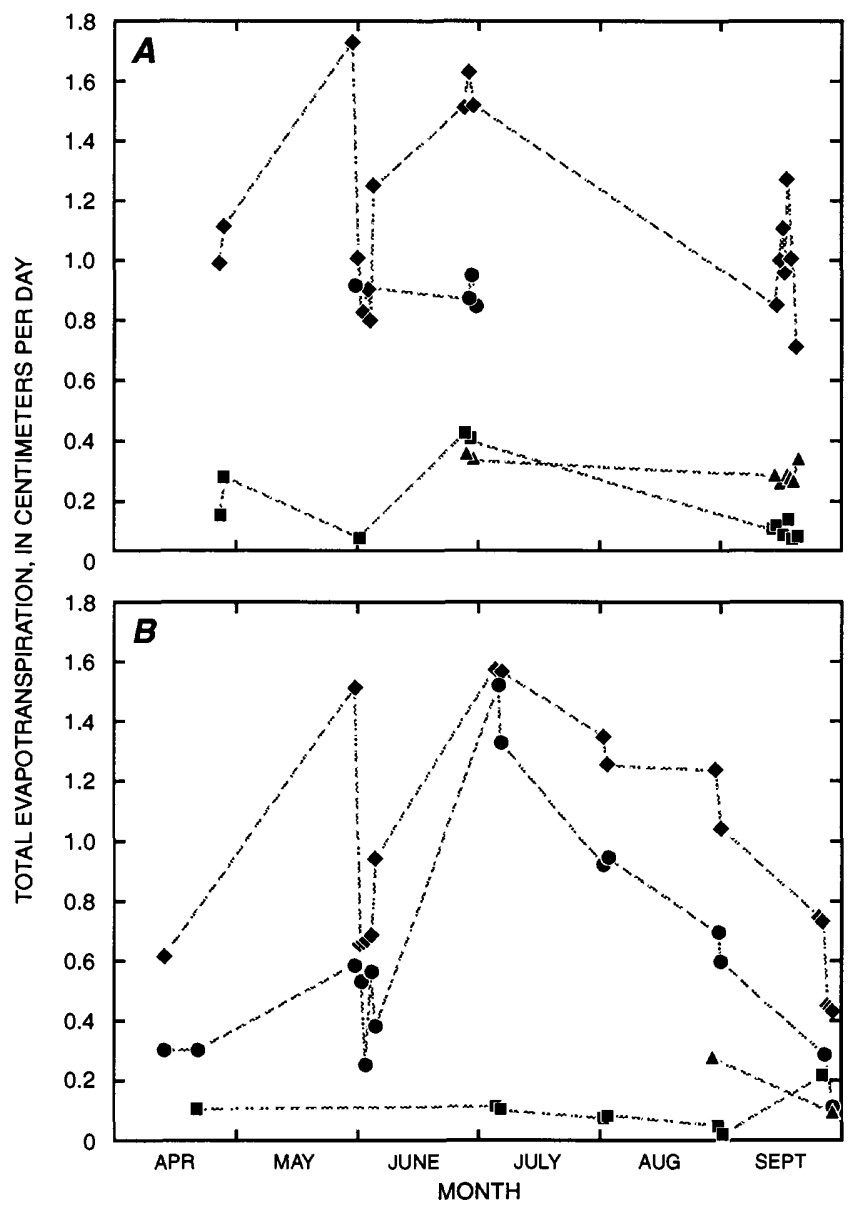

EXPLANATION

- Penman data

- Pan-evaporation data

- Eddy-correlation data

- Bowen ratio data

Figure 9. Total daily evapotranspiration for selected days during April through September 1983. $A$, Smith Creek Valley site. $B$, Soda Lake site.

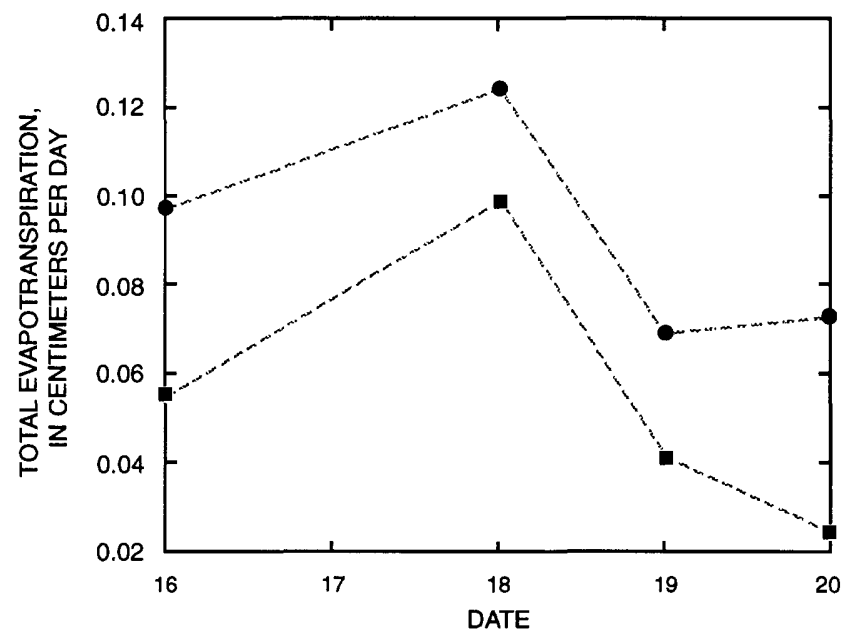

Figure 10. Total evapotranspiration estimated by eddycorrelation method for areas dominated by rabbitbrush (circle) and greasewood (square), September 16 and September 18-20, 1983, at Smith Creek Valley site. 
Table 3. Total evapotranspiration for 1983 derived from measured and residual values of latent-heat flux [Values in meters per year]

\begin{tabular}{|c|c|c|c|c|c|}
\hline \multirow[b]{2}{*}{ Site } & \multirow{2}{*}{$\begin{array}{l}\text { Eddy- } \\
\text { correlation } \\
\text { method }\end{array}$} & \multicolumn{3}{|c|}{ Measured evapotranspiration ${ }^{1}$} & \multirow{2}{*}{$\begin{array}{c}\text { Calculated }^{2} \\
\text { residual } \\
\text { evapotranspiration }\end{array}$} \\
\hline & & $\begin{array}{l}\text { Bowen ratio } \\
\text { method }\end{array}$ & $\begin{array}{l}\text { Penman } \\
\text { method }\end{array}$ & $\begin{array}{c}\text { Pan- } \\
\text { evaporation } \\
\text { method }\end{array}$ & \\
\hline $\begin{array}{l}\text { Smith Creek Valley } \\
\text { (rabbitbrush area). }\end{array}$ & 0.32 & 0.52 & 2.00 & 1.60 & 0.41 \\
\hline 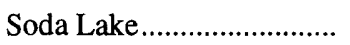 & .18 & .27 & 1.78 & 1.11 & .28 \\
\hline
\end{tabular}

${ }^{1}$ Annual values estimated by multiplying mean of full-day values (tables 1 and 2) by 180 days.

2 Residual latent-heat flux divided by latent heat of vaporization.

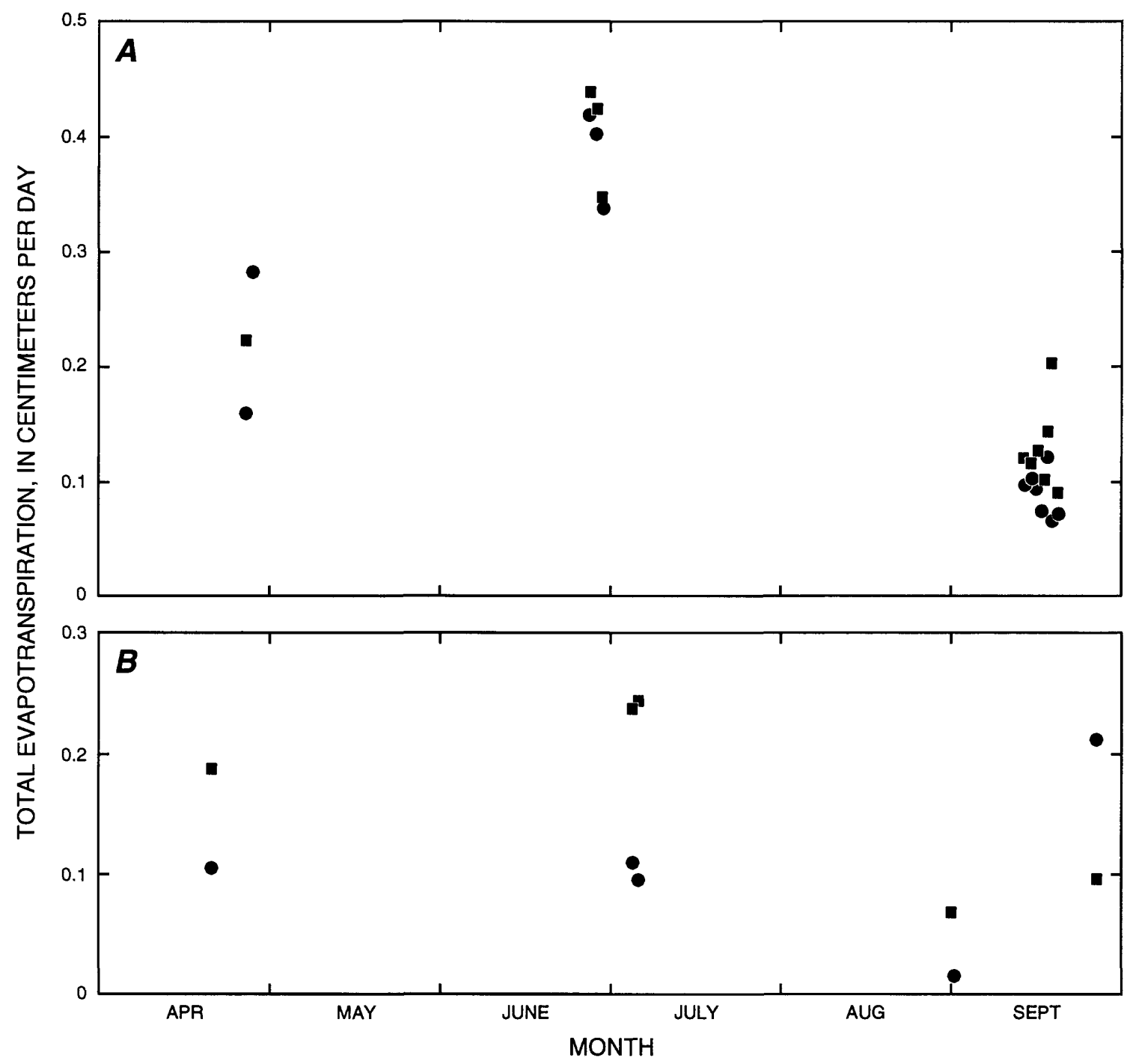

Figure 11. Evapotranspiration values derived from measured latent-heat flux (squares) and from calculated residual latent-heat flux (circles) for selected days during April through September 1983. $A$, Smith Creek Valley site. $B$, Soda Lake site. 


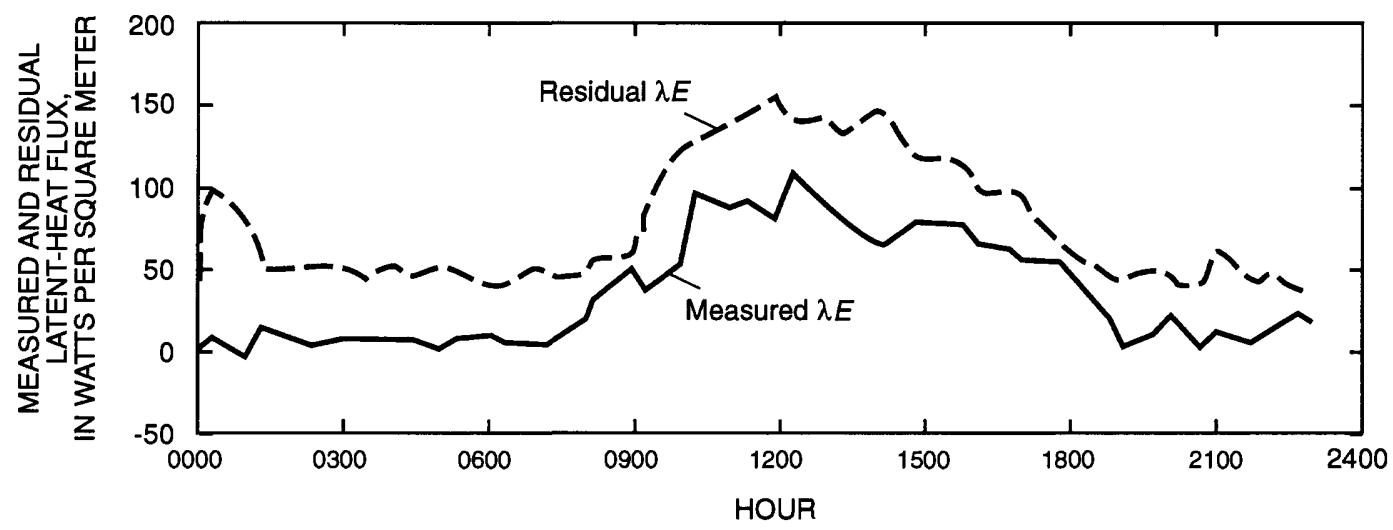

Figure 12. Measured (hourly) and residual latent-heat flux $(\lambda E)$ for September 18, 1983, at Smith Creek Valley site.

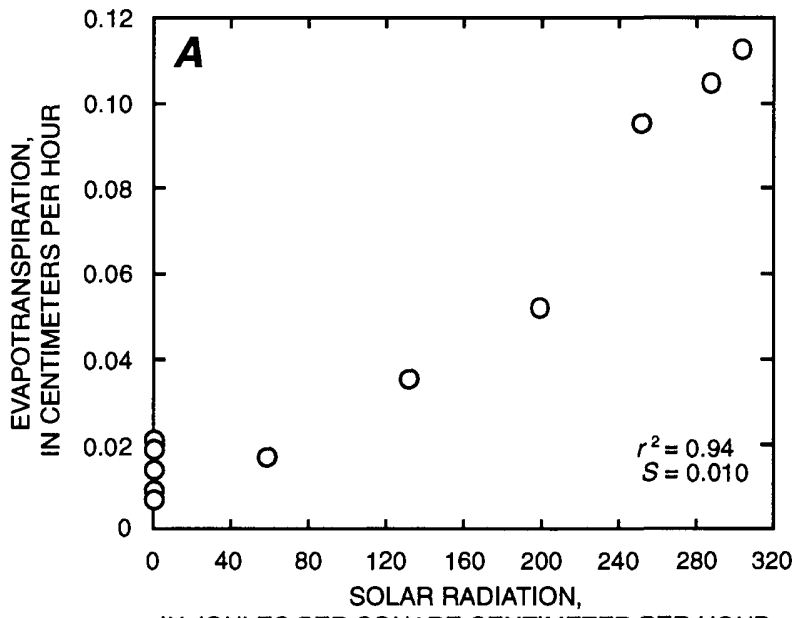

IN JOULES PER SQUARE CENTIMETER PER HOUR

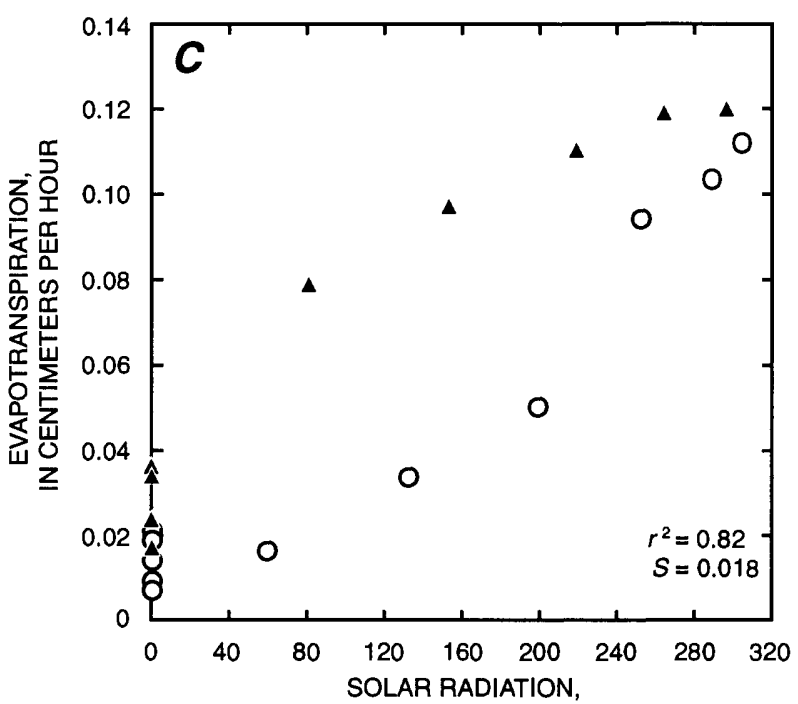

IN JOULES PER SQUARE CENTIMETER PER HOUR

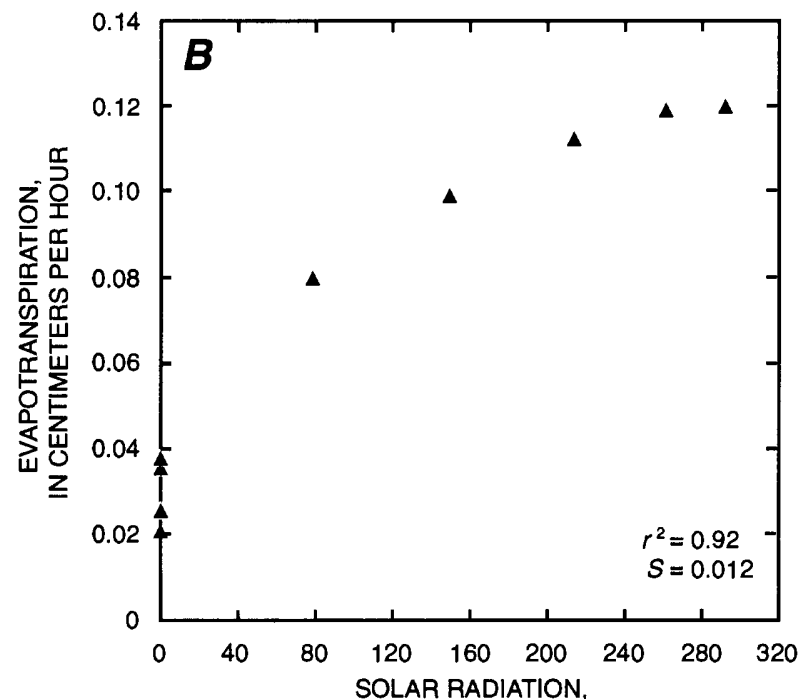

IN JOULES PER SQUARE CENTIMETER PER HOUR

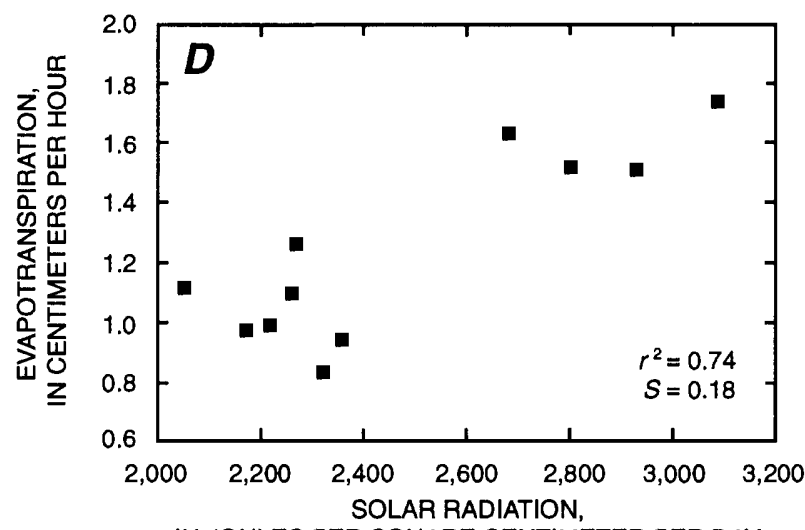

IN JOULES PER SQUARE CENTIMETER PER DAY

Figure 13. Relation between potential evapotranspiration and solar radiation at Smith Creek Valley site. $r^{2}$, coefficient of determination; s, standard deviation. A through C, Hourly data, September 18, 1983 (open circles: midnight-to-noon data; filled triangles: noon-to-midnight). $D$, Mean daily data for April through September 1983 (see table 1). 
perfect linear relation exists. Further statistical analysis with $t$ distributions shows that the correlation coefficients are highly significant and indicate a strong cause-and-effect relation. Standard deviations $(s)$ determined by the leastsquares method are shown in figure 13.

The relation between hourly ET and solar radiation for a selected day at the Smith Creek Valley site is shown in figures $13 A$ through $13 C$. (These data are also plotted against time in figure 7). In all three graphs, the high value of $r$ indicates a strong correlation between hourly ET and solar radiation. Daily ET and daily solar radiation are plotted in figure $13 D$; the data are for selected days at the Smith Creek Valley site (table 1). Although the points are scattered, the $r$ value indicates a good correlation between ET and solar radiation.

The relation between actual and potential ET at both sites is shown in figure 14A. Statistical analysis of the data indicates a strong correlation between actual and potential ET. The coefficients of correlation between daily total values of actual ET and potential ET were 0.86 and 0.93 for the Smith Creek Valley and Soda Lake sites, respectively (fig. 14B).
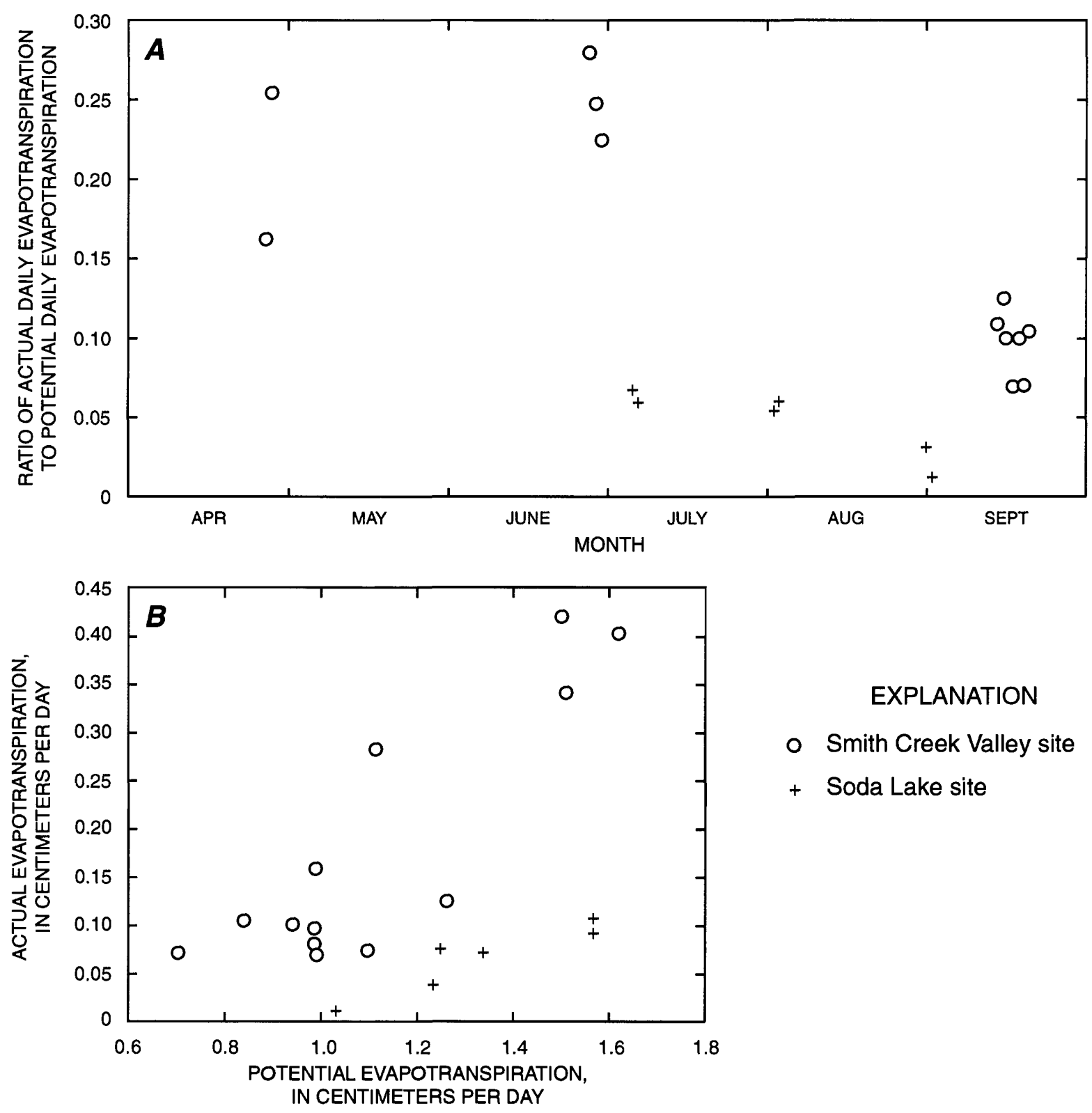

Figure 14. Relation between actual and potential evapotranspiration at Smith Creek Valley and Soda Lake sites for selected days, April through September 1983. A, Ratio of actual evapotranspiration to potential evapotranspiration. $B$, Actual evapotranspiration plotted against potential evapotranspiration. 
The correlation between measured soil-heat flux and potential ET (as determined by the Penman method) was poor; correlation coefficients were 0.2 or lower for the Smith Creek Valley site. This problem was remedied by using an estimated soil-heat flux obtained by multiplying the net radiation by a factor of 0.1 to 0.2 , depending on the amount of bare soil present (Campbell, 1977, p. 137). The poor correlation could have been the result of sand and soil blowing over the heat-flux plate and changing the depth at which measurements were being taken. Maintaining the desired depth was a constant problem at the Soda Lake site.

\section{Transfer Value}

Many factors have to be considered in evaluating the transfer value of the data derived by the methods described in this report, particularly the eddy-correlation method. An area's physical characteristics (such as depth to ground water, soil type, and salinity) and physiological characteristics (such as species, species density, cover density, plant size, and plant maturity) must be taken into account. Also, wide variation in precipitation from one part of the Great Basin to another contributes to variations in ET. In general, the transferability of the ET values to areas of similar vegetation, climate, and water depths should be good, although this has not been proven. More field-data collection is needed to further analyze possible transfer value.

\section{SUMMARY AND CONCLUSIONS}

The eddy-correlation and Penman methods are efficient methods for determining actual and potential evapotranspiration under natural conditions. The Bowen ratio method, which has had more widespread application, is useful for comparison with the eddy-correlation method.

Actual ET at the Smith Creek Valley and Soda Lake sites, estimated by the eddy-correlation method, was 32 and $18 \mathrm{~cm} / \mathrm{yr}$, respectively. Precipitation at the two sites during 1983 , an unusually wet year, was approximately 30 and 20 $\mathrm{cm}$, respectively. Had precipitation been average or below, ET probably would have exceeded precipitation or would have exceeded it by a greater margin. These values indicate that most, if not all, the precipitation is lost through ET at these sites, emphasizing the importance of ET in the water budget and the need to establish reliable means of determining ET rates.

High correlations of ET with solar radiation could make it possible to extrapolate ET data to similar areas where solar- or net-radiation data are collected.

The accuracy of the techniques and the simplicity and mobility of the instrumentation systems provide versatility not previously available and can provide valuable data in areas where ground water is a significant resource.

\section{REFERENCES CITED}

Brutsaert, W.H., 1982, Evaporation into the atmosphere: Boston, D. Reidel, $299 \mathrm{p}$.

Campbell, G.S., 1977, An introduction to environmental biophysics: New York, Springer-Verlag, 159 p.

Freund, J.E., 1973, Modern elementary statistics: New Jersey, Prentice-Hall, 532 p.

Fritschen, L.J., and Gay, L.W., 1979, Environmental instrumentation: New York, Springer-Verlag, 216 p.

Hanks, R.J., and Ashcroft, G.L., 1980, Applied soil physics-Soilwater and temperature applications: New York, SpringerVerlag, $159 \mathrm{p}$.

Hanson, R.L., and Dawdy, D.R., 1976, Accuracy of evapotranspiration rates determined by the water-budget method, Gila River flood plain, southeastern Arizona: U.S. Geological Survey Professional Paper 655-L, 40 p.

Jensen, M.E., and Haise, H.R., 1963, Estimating evapotranspiration from solar radiation: American Society of Civil Engineering, Journal of the Irrigation and Drainage Division, v. 89, p. 15-41.

National Oceanic and Atmospheric Administration, 1983, Climatological data, Nevada: U.S. Department of Commerce, v. 98, nos. 1-12, $253 \mathrm{p}$.

Penman, H.L., 1948, Natural evaporation from open water, bare soil, and grass: Proceedings of the Royal Society of London, v. 193 , p. $120-145$.

Pennington, R.W., 1980, Evaluation of empirical methods for estimating crop water consumptive use for selected sites in Nevada: Nevada Division of Water Planning Report 3, 206 p.

Robinson, T.W., 1970, Evapotranspiration by woody phreatophytes in the Humboldt River Valley near Winnemucca, Nevada: U.S. Geological Survey Professional Paper 491-D, $12 \mathrm{p}$.

Schwerdtfeger, Peter, 1976, Physical principles of micrometeorological measurements, v. 6 of Developments in Atmospheric Science: New York, Elsevier, 113 p.

Van Hylckama, T.E.A., 1980, Weather and evapotranspiration studies in a saltcedar thicket, Arizona: U.S. Geological Survey Professional Paper 491-F, 53 p.

Wilson, R.G., and Rouse, W.R., 1971, Moisture and temperature equilibrium evapotranspiration model: Journal of Applied Meteorology, v. 11, p. 436-442. 